\title{
Nesfatin-1: functions and physiology of a novel regulatory peptide
}

\author{
Riccardo Dore, Luka Levata, Hendrik Lehnert and Carla Schulz
}

Department of Internal Medicine I, Center of Brain, Behavior and Metabolism (CBBM), University of Lübeck, Lübeck, Germany

Correspondence should be addressed to C Schulz Email

carla.schulz@uksh.de

\begin{abstract}
Nesfatin-1 was identified in 2006 as a potent anorexigenic peptide involved in the regulation of homeostatic feeding. It is processed from the precursor-peptide NEFA/ nucleobindin 2 (NUCB2), which is expressed both in the central nervous system as well as in the periphery, from where it can access the brain via non-saturable transmembrane diffusion. In hypothalamus and brainstem, nesfatin-1 recruits the oxytocin, the melancortin and other systems to relay its anorexigenic properties. NUCB2/nesfatin-1 peptide expression in reward-related areas suggests that nesfatin-1 might also be involved in hedonic feeding. Besides its initially discovered anorexigenic properties, over the last years, other important functions of nesfatin-1 have been discovered, many of them related to energy homeostasis, e.g. energy expenditure and glucose homeostasis. Nesfatin-1 is not only affecting these physiological processes but also the alterations of the metabolic state (e.g. fat mass, glycemic state) have an impact on the synthesis and release of NUCB2 and/or nesfatin-1. Furthermore, nesfatin-1 exerts pleiotropic actions at the level of cardiovascular and digestive systems, as well as plays a role in stress response, behavior, sleep and reproduction. Despite the recent advances in nesfatin-1 research, a putative receptor has not been identified and furthermore potentially distinct functions of nesfatin-1 and its precursor NUCB2 have not been dissected yet. To tackle these open questions will be the major objectives of future research to broaden our knowledge on NUCB2/nesfatin-1.
\end{abstract}

Journal of Endocrinology (2017) 232, R45-R65

\section{Introduction}

In quest of novel appetite regulating molecules, in 2006, Oh-I and coworkers re-discovered NEFA/nucleobindin2 (Nucb2), a peroxisome proliferator $\gamma$ receptor (PPARG)-activated gene in immortalized cell lines (Oh-I et al. 2006) and later in the hypothalamus of rodents (Oh-I et al. 2006). Its gene product NUCB2, a 396 amino acid (AA) peptide, which was originally described as a secreted protein of unknown function (Miura et al. 1992, Barnikol-Watanabe et al. 1994), possesses a number of putative cleavage sites, suggesting further processing (Oh-I et al. 2006). The N-terminal fragment, named nesfatin-1, was subsequently identified in rat cerebrospinal fluid
(CSF) and the hypothalamic paraventricular nucleus (PVN), and it was found to dose-dependently reduce food intake when administered intracerebroventricularly (i.c.v.) in rodents (Oh-I et al. 2006). Since the seminal work by Oh-I et al. (2006), numerous research groups have aimed at elucidating the role of nesfatin- 1 not only in the regulation of food intake but also in other physiological functions. With this review, we aim at summarizing the current knowledge in the field with a particular focus on energy homeostasis. Furthermore, we provide comprehensive tables on nesfatin-1 administration, dosages and physiological effects.

Published by Bioscientifica Ltd. 


\section{NUCB2 and nesfatin-1: expression, processing} and release

Nucb2 mRNA is mainly expressed in gastric mucosa and white adipose tissue and also, but to a minor extent, in other peripheral organs, e.g. pancreas and testis (Gonzalez et al. 2009, Shimizu et al. 2009b, Stengel et al. 2009b, Ramanjaneya et al. 2010, Kim et al. 2014). Within the central nervous system (CNS), Nucb2 mRNA is present, for example, in the hypothalamus and brainstem (Oh-I et al. 2006, Brailoiu et al. 2007) (for more details we refer to the respective sections).

The product of the $N u c b 2$ gene is a 420 AA peptide consisting of a 24 AA signal peptide and 396 AA peptide termed NUCB2. The latter possesses putative cleaving sites for protein convertases (PC) $1 / 3$ and PC2, suggesting further processing into three alleged fragments: nesfatin-1 (AA 1-82), nesfatin-2 (AA 85-163) and nesfatin-3 (AA 166-396) (Oh-I et al. 2006). NUCB2 is co-localized with these enzymes in the cytoplasm (Steiner et al. 1992, Oh-I et al. 2006, Mohan et al. 2014, 2016), suggesting that processing of NUCB2 may take place physiologically. However, to our knowledge, this has not been proven so far by in vivo and in in vitro studies; Chinese hamster ovary (CHO) cells overexpressing the relevant genes (Nucb2, $P c 1 / 3, P c 2$ ), failed to produce nesfatin-1 (Oh-I et al. 2013). Alternatively, other enzymes, for example, the cell surface membrane-bound protein furin, which cleaves at the same general motif as the PCs, might be involved in NUCB2 processing (Seidah \& Prat 2002). In most rodent tissues studied, for example, gastric mucosa, pancreas, pituitary gland and testis, either only the precursor NUCB2 or indistinguishable NUCB2/nesfatin-1 was detected (Stengel et al. 2009b, Kim et al. 2014). However, nesfatin-1, the amino terminal putative cleavage product of NUCB2, was unambiguously identified in the hypothalamus and CSF of rodents (Oh-I et al. 2006) and also in human plasma (Tsuchiya et al. 2010).

Although this clearly proves the existence of nesfatin-1 in vivo, it is still unknown whether the putative cleavage products nesfatin- 2 and -3 exist and are secreted in vivo. The administration of neither nesfatin-2 nor -3 was effective in terms of food intake (Oh-I et al. 2006). For the biological action, the mid-segment of nesfatin-1, which corresponds to AA 24-53 of NUCB2 and nesfatin-1, is of particular relevance (Shimizu et al. 2009a, Stengel et al. 2012, Prinz et al. 2015).

On the cellular level, at least in the PVN, nesfatin-1 is located mainly in secretory vesicles in perikarya near the Golgi apparatus, but not in axon terminals, suggesting a dendritic release and thus eventually autocrine or paracrine actions (Maejima et al. 2009). Likewise, in the periphery, NUCB2/nesfatin-1 immunoreactivity was detected in intracellular vesicles of gastric oxyntic mucosa and endocrine cells of pancreatic islets and the anterior pituitary (Stengel et al. 2009b).

As mentioned previously, NUCB2 is expressed both in the CNS as well as in peripheral tissues, and it has been shown that nesfatin-1 can also cross the blood-brain barrier (BBB) by non-saturable transmembrane diffusion, consistent with its low lipophilicity (Pan et al. 2007, Price et al. 2007). This finding suggests that peripheral nesfatin-1 (either endogenous or exogenous) may access the CNS to exert biological actions.

Of note, many publications state that nesfatin-1 was detected by antibody (Ab)-based methods (e.g. immunohistochemistry, immunoassays). However, in most cases, this statement is not justified, since with rare exceptions (e.g. Oh-I et al. 2006, Celik et al. 2013), the assays used could not distinguish between proteolytically cleaved nesfatin- 1 and fulllength NUCB2. Only in some studies, western blots were performed to distinguish between NUCB2 and nesfatin-1 based on the molecular weight (e.g. Stengel et al. 2009b, Kim et al. 2014). Throughout this review, the term 'NUCB2/nesfatin- 1 ' is used whenever one or the other was not positively identified.

\section{Nesfatin-1: signal transduction}

Although the putative NUCB2/nesfatin-1 receptor has not yet been identified, specific binding sites for nesfatin-1 were detected both in the CNS (e.g. hypothalamus, cortex) and peripheral organs (e.g. gastrointestinal system, pituitary, pancreas) (Ishida et al. 2012, Prinz et al. 2016).

Some studies have investigated intracellular signaling events of nesfatin-1 not only in various cell types, e.g. in hypothalamic, nucleus ambiguus or dorsal root ganglia (DRG) neurons or neuronal cell lines but also in pancreatic $\beta$-cells and cardiac myocytes.

As a universal principle, in most cell types, nesfatin-1 stimulates $\mathrm{Ca}^{2+}$ influx either through L- (Brailoiu et al. 2007, Nakata et al. 2011, Ishida et al. 2012), P/Q- (Brailoiu et al. 2007, 2013) or N- (Iwasaki et al. 2009) type $\mathrm{Ca}^{2+}$ channels. Both neuronal depolarization (Brailoiu et al. 2013) as well as the increase in intracellular $\mathrm{Ca}^{2+}$ (Brailoiu et al. 2007, 2013, Ozcan et al. 2016) were prevented by pretreatment with pertussis toxin, indicating the involvement of a $\mathrm{G}_{\mathrm{i}}$-protein-coupled receptor. Accordingly, no increase

Published by Bioscientifica Ltd. 
in cyclic adenosine monophosphate (cAMP) formation was observed (Ishida et al. 2012). Nevertheless, CREB phosphorylation was increased in a neuroblastoma cell line (Ishida et al. 2012), however, not in vivo (Tanida et al. 2015). The activation of protein kinase A (PKA) appears to differ across tissues and might indicate a tissue-specific recruitment of G-protein subunits (Brailoiu et al. 2007, Nakata et al. 2011, Ishida et al. 2012). In addition to these established G-protein-related pathways, in cardiac myocytes and DRG neurons, nesfatin-1 acts to inhibit L-type $\mathrm{Ca}^{2+}$ channels through protein kinase C (PKC), indicating an involvement of $\mathrm{G}_{\mathrm{q}}$ (Ying et al. 2015, Ozcan et al. 2016). These findings, albeit unequivocal with regard to the type of G-proteins involved, suggest the existence of one or more 7-transmembrane receptor(s). Furthermore, mitogen-activated protein kinases (MAPK) (extracellular signal-regulated kinase (ERK1/2)) (Ishida et al. 2012, Angelone et al. 2013, Tanida et al. 2015) is activated by nesfatin-1; 5' AMP-activated protein kinase (AMPK) and phosphatidylinositol-3-kinases (PI3K), however, do not appear to be involved (Tanida et al. 2015).

The current findings on intracellular signaling events have to be interpreted with caution as they might not be directly linked to a putative NUCB2/nesfatin-1 receptor. Some of the observed intracellular consequences, e.g. the nesfatin-1-induced activation of a cAMP response element (Cre)-reporter in a transfected neuroblastoma cell line (Ishida et al. 2012) and the suppression of cardiac L-type $\mathrm{Ca}^{2+}$ channels (Ying et al. 2015), are attenuated by the melanocortin receptor (MC) 3/4 antagonist SHU9119 (Ishida et al. 2012, Ying et al. 2015). Provided that nesfatin-1 is not directly acting at the MC3/4 (Oh-I et al. 2006), this could indicate that some observations are not signaling events of a putative NUCB2/nesfatin-1 receptor. They could rather result from intracellular signaling cascades of receptors downstream the alleged NUCB2/ nesfatin-1 receptor, e.g. the MC3 or 4.

\section{Genetics}

Different polymorphisms of the Nucb2 gene have been associated with body weight in correlation studies. Based on the frequency of these polymorphisms in lean vs obese subjects some of them were implied to promote obesity (Zegers et al. 2012), whereas others rather seem to protect from it (Zegers et al. 2011). Specifically, the 1012C > G polymorphism reduces the susceptibility for the development of an obese phenotype. The GG genotype is more frequent in healthy, lean individuals than in obese children (Chen et al. 2013) and patients suffering from the metabolic syndrome (Wang et al. 2016), and its presence in the latter patients is associated with lower fasting glucose levels (Wang et al. 2016). These findings in metabolic syndrome patients are complemented by the negative association of this polymorphism with blood pressure (Tragante et al. 2014).

\section{Energy homeostasis}

\section{Homeostatic regulation of food and water intake}

Oh-I et al. (2006) were the first to demonstrate that both nesfatin-1 and its precursor NUCB2 possess anorexigenic properties. A third ventricle injection of either NUCB2 or nesfatin-1 at similar doses reduces food intake in ad libitum fed rats during the dark phase in Oh-I et al. (2006). The application of the two other putative cleavage products of NUCB2, nesfatin-2 and/or nesfatin-3 was not effective. Moreover, the anorexigenic effect of nesfatin- 1 is independent from leptin because it is still present in leptin-resistant Zucker rats (Brunner et al. 1997, Oh-I et al. 2006). Conversely, third ventricle acute administration of a nesfatin- $1 \mathrm{Ab}$ as well as daily injection of a Nucb2 antisense oligonucleotide over 10 days increase food intake, thus suggesting that endogenous levels of NUCB2/nesfatin-1 play a role in regulating feeding behavior (Oh-I et al. 2006).

Nesfatin-1's anorexigenic effect was confirmed in further studies where nesfatin-1 was injected centrally in ad libitum fed rats and mice (Maejima et al. 2009, Stengel et al. 2009a, Yosten \& Samson 2009, 2010, Goebel et al. 2011, Könczöl et al. 2012, Gotoh et al. 2013) and fasted animals (Yosten \& Samson 2009, Atsuchi et al. 2010, Wernecke et al. 2014). Only in one study nesfatin-1 failed to suppress light-phase food intake in fasted animals when given into the cisterna magna (Stengel et al. 2009a). When given intranasally, nesfatin-1 reduces cumulative food intake (Shimizu et al. 2009b), similar to leptin (Schulz et al. 2004, 2012, Fliedner et al. 2006), most likely by directly accessing the brain and thus bypassing the BBB. As Nucb2 mRNA and protein are expressed in the periphery, the effects of its putative cleavage product nesfatin-1 (and segments thereof) in suppressing food intake after peripheral administration were also studied. Intraperitoneal (i.p.) acute administration of nesfatin-1 midsegment decreased food intake in both lean and $d b / d b$ leptin-resistant obese mice (Shimizu et al. 2009a), thus suggesting that also peripheral nesfatin- 1 induces anorexia in a leptin-independent manner. Peripheral

Published by Bioscientifica Ltd. 
nesfatin-1 can potentially affect central nervous food intake regulation either via direct access to the brain, vagal afferents or via endocrine messengers, e.g. cholecystokinin (CCK). How and to which extent these different means of signaling are of physiological relevance, remains to be elucidated.

Although endogenous NUCB2/nesfatin-1 itself regulates feeding behavior, its expression can also be regulated by the feeding state. In rodents, Nucb2 mRNA and NUCB2/nesfatin-1 protein levels were found to be reduced by fasting, and normalized by refeeding, both centrally in the supraoptic nucleus (SON) and PVN (Oh-I et al. 2006, Kohno et al. 2008, Garcia-Galiano et al. 2010) as well as peripherally in subcutaneous adipose tissue (Ramanjaneya et al. 2010) and plasma (Stengel et al. 2009a). Fittingly, mice fed a high-fat diet for 12 or 20 weeks show an increase in NUCB2 protein expression in subcutaneous adipose tissue (Ramanjaneya et al. 2010). In addition, an acute gavage with a high fat bolus also increased serum NUCB2/nesfatin-1 levels in mice (Mohan et al. 2014). Finally, peripheral and central acute injection of nesfatin-1 midsegment reduced food intake in mice fed a high-fat diet (Shimizu et al. 2009a, Prinz et al. 2015), whereas leptin did not (Shimizu et al. $2009 a$ ), indicating that long term exposure to high-fat diet did not cause 'nesfatin-1 resistance' analogous to the well-described leptin-resistance (Crujeiras et al. 2015). Thus, nesfatin- 1 could represent a valid alternative in the treatment of metabolic diseases even in the state of leptin resistance.

As mentioned, nesfatin-1 exerts its anorexigenic functions in a leptin-independent manner. Rather, nesfatin-1 signaling seems to be important in mediating leptin-induced anorexia. Recently, it was shown that leptin increases Nucb2 mRNA expression in the PVN both in vitro and in vivo (Darambazar et al. 2015). In agreement with this, in PVN NUCB2-knockdown mice, both peripheral and central administration of leptin failed to induce anorexia (Darambazar et al. 2015). Moreover, central co-administration of leptin and nesfatin-1 did not yield larger effects on energy expenditure than nesfatin-1 or leptin alone, possibly suggesting common downstream signaling mechanisms (Wernecke et al. 2014). However, when endogenous nesfatin-1 was blocked by the administration of an Ab, leptin was still capable to induce anorexia (Oh-I et al. 2006). Further studies are needed to clarify the functional relationship between these two adipokines.

The nesfatinergic system was shown to interact with a number of systems known to regulate feeding behavior. For instance, the anorexigenic effect induced by nesfatin-1 is blocked by the central administration of the MC3/4 receptor antagonist SHU9119 (Oh-I et al. 2006, Yosten \& Samson 2009). Contrary to peripheral leptin actions (Huo et al. 2006, Perello et al. 2007), central or peripheral administration of nesfatin-1 or its midsegment increased proopiomelanocortin (POMC) and cocaine- and amphetamine-related transcript (CART) mRNA expression in the nucleus of the solitary tract (NTS), but not at the hypothalamic level in rats (Oh-I et al. 2006, Shimizu et al. 2009a, Wernecke et al. 2014). The interaction between these two systems is further supported by the finding that $\alpha$-melanocyte-stimulating hormone (a-MSH) administration increased Nucb2 mRNA expression (Oh-I et al. 2006) and activated NUCB2/nesfatin-1 neurons (Sedbazar et al. 2014) in the PVN.

The anorexigenic effect of nesfatin-1 seems to be, at least in part, mediated by oxytocinergic neurons. In fact, nesfatin-1 was demonstrated to be co-localized with oxytocin within the SON and PVN (Foo et al. 2008, Kohno et al. 2008). The excitability of oxytocinergic neurons of the PVN was influenced by nesfatin-1 in vitro (Price et al. 2008a). Strikingly, endogenous nesfatin-1 was shown to alter oxytocin release in PVN slices (Maejima et al. 2009). However, central administration of nesfatin-1 did not affect plasma basal levels of oxytocin in rats (Yosten \& Samson 2010), indicating that axonal oxytocin release from magnocellular PVN and/or SON neurons was unaffected. The reduction of cumulative food intake induced by central nesfatin-1 was blocked by the coadministration of a selective antagonist for the oxytocin receptor (H4928) (Maejima et al. 2009, Yosten $\&$ Samson 2010). When injected site specifically into the PVN, nesfatin-1 suppressed feeding by the stimulation of the oxytocin system, together with an increased in c-fos expression in the NTS, suggesting that oxytocinergic neurons projecting from PVN to the NTS are modulated by nesfatin-1 to induce anorexia (Maejima et al. 2009).

The nesfatinergic system was also found to interact with the corticotropin-releasing factor (CRF)/CRF receptor system to modulate feeding behavior (see below). Co-localization of nesfatin-1 with CRF within the PVN was observed (Foo et al. 2008, Kohno et al. 2008). In agreement, nesfatin-1 was shown to influence the excitability of Crf-expressing neurons in vitro (Price et al. 2008a) as well as to increase CRF protein levels (Gotoh et al. 2013) in the PVN. The administration of a specific $\mathrm{CRF}_{2}$ receptor antagonist (astressin ${ }_{2}-\mathrm{B}$ ) injected into the forebrain, but not into the hindbrain, fully abolished the anorexigenic effect of nesfatin-1 (Stengel et al. 2009a).

Published by Bioscientifica Ltd 
NUCB2/nesfatin-1 were shown to be expressed and co-localized with the orexigenic peptide neuropeptide $\mathrm{Y}$ (NPY) in the arcuate nucleus (ARC) (Oh-I et al. 2006, Brailoiu et al. 2007, Inhoff et al. 2010). An in vitro electrophysiological study demonstrated that the majority of Npy-expressing neurons in the ARC was hyperpolarized by nesfatin-1 (Price et al. 2008b), indicating that nesfatin-1 could suppress food intake by downregulating NPY signaling. In agreement, rats administered i.c.v. with nesfatin-1 showed decreased Npy mRNA expression in the hypothalamus and NTS (Wernecke et al. 2014). Also, NUCB2/nesfatin-1 neurons of the PVN were inhibited by NPY in vitro (Sedbazar et al. 2014), confirming that nesfatin-1 and NPY interact within the PVN-ARC-feeding center. Lastly, it was also found that the orexigenic effect of peripheral ghrelin was blocked by desacyl ghrelin via activation of NUCB2/nesfatin-1 neurons of the ARC (Inhoff et al. 2008).

In one study the interaction between nesfatin- 1 and the serotoninergic system was addressed. The serotonin $5 \mathrm{HT}_{1 \mathrm{~B} / 2 \mathrm{C}}$ receptor agonist, m-chlorophenylpiperazine, induced anorexia in a leptin-independent manner by upregulating $N u c b 2$ expression in the hypothalamus (Nonogaki et al. 2008). Such effects were blunted in $5 \mathrm{HT}_{2 \mathrm{C}}$ receptor mutant mice (Nonogaki et al. 2008), suggesting that activation of $5 \mathrm{HT}_{2 \mathrm{C}}$ receptors might play a role in regulating $N u c b 2$ expression and, in turn, feeding behavior. Pharmacological treatment with olanzapine, a neuroleptic, which acts as an inverse agonist on the $5 \mathrm{HT}_{2 \mathrm{C}}$ receptor, was shown to decrease NUCB2/nesfatin-1 expression in hypothalamic feeding-related areas of rats, leading the authors to speculate that olanzapine could enhance food intake and in turn body weight gain partly by downregulating NUCB2/nesfatin-1 expression (Rojczyk et al. 2015). Finally, in another study, the involvement of histamine and thyrotropin-releasing hormone (TRH) in mediating nesfatin-1's effects was investigated (Gotoh et al. 2013). Histamine is known to potently reduce appetite and (Masaki et al. 2004) and NUCB2/nesfatin-1 was found to be expressed in the tuberal hypothalamic area (THA) (Fort et al. 2008) where histaminergic neurons are exclusively localized (Giannoni et al. 2009). It was found that central administration of histamine increased NUCB2/nesfatin-1 peptide expression in the PVN and in turn, central administration of nesfatin-1 increased the turnover of histamine in the hypothalamus. Moreover, the anorexigenic effect of nesfatin-1 was reduced in animals with disrupted histamine signaling (Gotoh et al. 2013). Finally, administration of nesfatin-1 resulted in an increase in TRH mRNA expression in the PVN and the anorexigenic effect of nesfatin-1 was attenuated when an $\mathrm{Ab}$ against TRH was co-administered (Gotoh et al. 2013).

Nesfatin-1 was also shown to alter meal pattern. In mice, central administration of nesfatin- 1 reduced meal size and increased inter-meal intervals indicating both satiety (meal termination) and satiation (delayed meal initiation) (Goebel et al. 2011), whereas central injection of nesfatin-1 midsegment induced satiety without affecting satiation (Stengel et al. 2012). Interestingly, in rats fed normal chow, central nesfatin-1 midsegment induced satiation, whereas satiety was induced in rats with diet-induced obesity (Prinz et al. 2015). As suggested by the authors, these mixed results could be explained by differences in species, receptor-binding affinity between full-length nesfatin-1 vs its midsegment and/or the activation of different signaling pathways depending on dietary conditions (Prinz et al. 2015). In a recent study, treatment with nesfatin-1 resulted in the upregulation of $C c k$ (a satiation peptide) and in the downregulation of peptide $Y y$ (PYY, a satiety peptide) mRNA and protein levels both in vitro and in vivo (Ramesh et al. 2016).

For a comprehensive overview of nesfatin-1's effects on homeostatic food intake regulation, please refer to Table 1.

Nesfatin-1 was shown to be involved not only in feeding behavior but also in body fluid regulation (Yosten \& Samson 2009, 2010, Könczöl et al. 2012, Yosten et al. 2012, Yoshimura et al. 2014). This was first demonstrated by Yosten and Samson (2009) who showed that nesfatin-1 reduces water intake when injected i.c.v., an effect mediated by MC3/4 and oxytocin receptors (Yosten \& Samson 2009, 2010). Interestingly, nesfatin-1's antidipsogenic effect had an earlier onset with respect to the anorexigenic effect (60 min vs $150 \mathrm{~min}$ ) (Yosten \& Samson 2009), raising the possibility that the reduction of food intake might be a consequence of the reduced fluid intake. In addition, reduction of intake elicited by nesfatin-1 was more pronounced in water than in food (70\% vs 50\%, respectively) (Yosten \& Samson 2009).

Intracerebroventricular nesfatin-1 dose-dependently attenuates the water drinking response to angiotensin II, to overnight fluid restriction, and to hypertonic saline (Yosten et al. 2012). Consistent with other data (Oh-I et al. 2006), a 2-day treatment with antisense morpholino oligonucleotide against Nucb2 gene resulted in a reduction of NUCB2/nesfatin-1 in the PVN without altering water intake (Yosten et al. 2012); however, drinking response upon angiotensin II administration was exaggerated (Yosten et al. 2012).

Published by Bioscientifica Ltd 


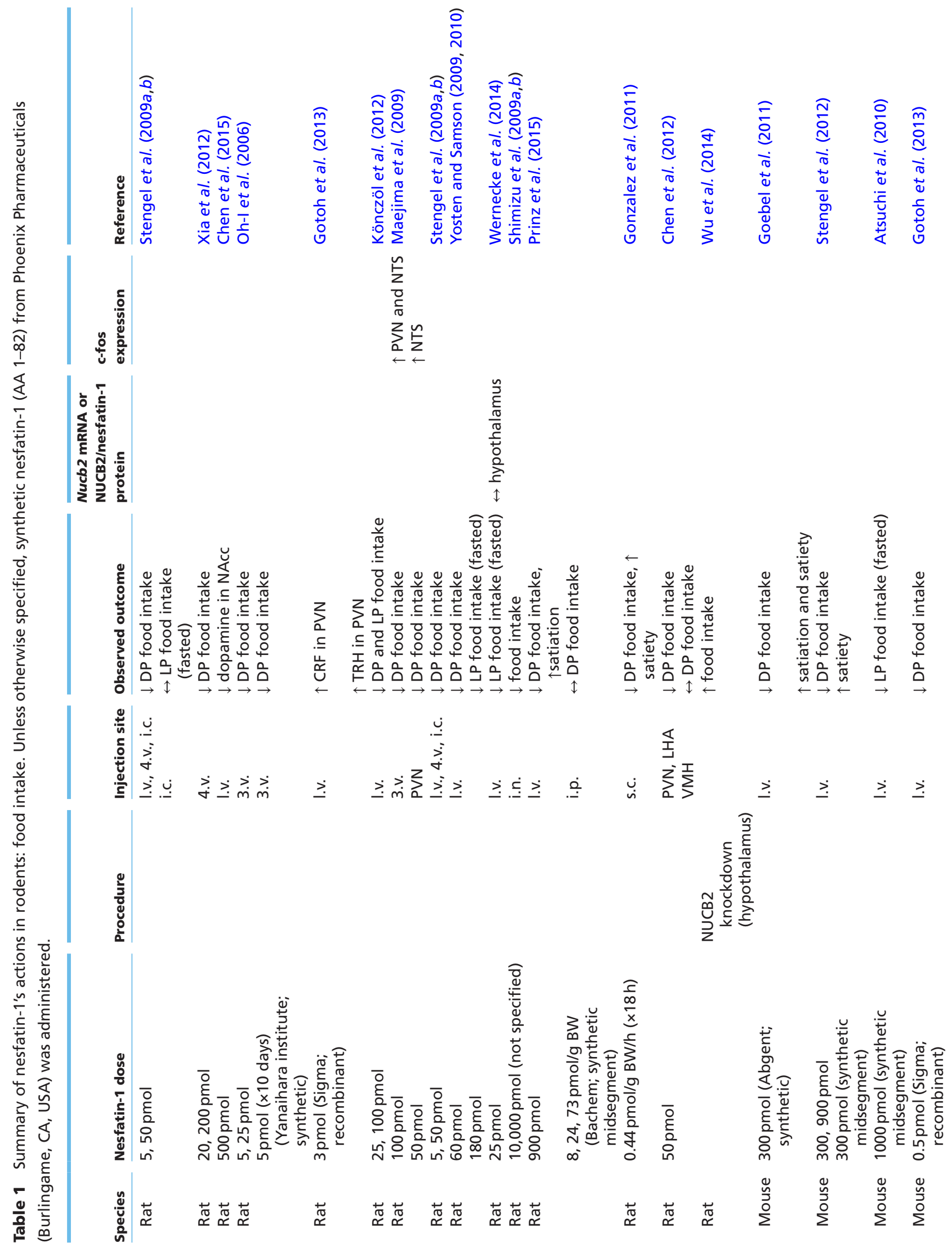


Nucb2 mRNA is expressed in the subfornical organ (SFO), an area involved in body fluid regulation (Hindmarch et al. 2008, Kuksis \& Ferguson 2014). An in vitro electrophysiological study demonstrated the capability of SFO neurons to respond to nesfatin-1 (Kuksis \& Ferguson 2014). Consistently, i.c.v. nesfatin-1 administration increases c-fos immunoreactivity in the SFO as well as in the PVN and central nucleus of the amygdala (CeA). As a functional correlate, nesfatin-1 injected into the SFO increases water intake independent from the angiotensin system; however, this was only observed in the absence of food (Moreau \& Ciriello 2013).

Prolonged water deprivation increases $N u c b 2$ mRNA and NUCB2/nesfatin-1 protein levels in the SFO as well as in the SON and PVN (Yoshimura et al. 2014), which are normalized upon rehydration (Yoshimura et al. 2014); in contrast, water deprivation reduces $N u c b 2$ mRNA levels in the total hypothalamus (Yosten et al. 2012), thus suggesting that water deprivation might have decreased Nucb2 mRNA levels in other hypothalamic nuclei than the former.

A summary of nesfatin-1's effects on water intake is given in the Supplementary Table 1, see section on supplementary data given at the end of this article.

\section{Hedonic regulation of food intake}

A growing body of evidence suggests that nesfatin-1 might be involved not only in regulating homeostatic feeding but also in the reward-related aspects of feeding behavior. In fact, NUCB2/nesfatin-1 protein is expressed in reward-related areas such as amygdaloid nucleus, nucleus accumbens (NAcc), lateral hypothalamus and dorsal raphe nuclei (DR) (Goebel-Stengel et al. 2011). In an in vitro study, Li et al. (2014) demonstrated nesfatin1 's capability to hyperpolarize dopaminergic neurons of the substantia nigra, a brain area involved not only in sensorimotor functions but also in reward and aversion (Ilango et al. 2014). Furthermore, nesfatin-1 decreased the resting membrane potential and firing rate of dopaminergic neurons most likely by a direct mechanism (Li et al. 2014). Dopaminergic neurons originating from the ventral tegmental area (VTA) innervate the NAcc and release dopamine in response to rewarding (or aversive) stimuli. Interestingly, i.c.v. nesfatin-1 decreases dopamine release in the NAcc (Chen et al. 2015). Furthermore, when nesfatin-1 was injected directly into the VTA, the reduction in chow food intake arises at an earlier onset than when it is injected i.c.v. in mice ( $1 \mathrm{~h}$ vs $3 \mathrm{~h}$; respectively) 
(Goebel et al. 2011, Stengel et al. 2012, Chen et al. 2015). However, how and to which extent nesfatin-1 is involved in the modulation of 'wanting', 'liking', and/or other reward-related behaviors is currently unknown.

Whether nesfatin-1 acts directly or also recruits other neurotransmitter systems to modulate reward pathways is yet to be elucidated. One possibility is that NUCB2/nesfatin-1 neurons interact with melanocortin and oxytocin systems, which are mediating nesfatin1 's effects on homeostatic food intake (Oh-I et al. 2006, Maejima et al. 2009, Yosten \& Samson 2009, 2010). In support of this idea, melanocortins and oxytocin were shown to regulate not only homeostatic feeding (Saper et al. 2002, Sabatier et al. 2013) but also play a role in the modulation of hedonic pathways. Recently, it was shown that motivation to obtain sucrose in rats is downregulated by the activation of MC3 within rewardrelated areas (Pandit et al. 2015, 2016). Similarly, oxytocin reduces methamphetamine-induced seeking behavior in rodents (Cox et al. 2013) and reward-driven food intake in humans (Ott et al. 2013).

A second possible scenario might be the interaction between the nesfatin-1 and ghrelin systems. Ghrelin and nesfatin-1 are co-expressed in X/A endocrine cells of the gastric mucosa (Stengel \& Taché 2009, Stengel et al. 2009b). Ghrelin regulates homeostatic feeding by increasing food intake in both rodents and humans (Wren et al. 2000, 2001, Gil-Campos et al. 2006). An interaction of nesfatin-1 and ghrelin is also supported by data showing their co-localization in goldfish hypothalamus (Kerbel \& Unniappan 2012). Moreover, i.c.v. nesfatin-1 suppresses food intake and downregulates preproghrelin and ghrelin receptor mRNA expression in the forebrain of fed fish (Kerbel \& Unniappan 2012). In a similar fashion, i.c.v. ghrelin promotes food intake and downregulates Nucb2 mRNA expression in the forebrain (Kerbel \& Unniappan 2012). Accordingly, lipopolysaccharideinduced acute inflammation in rats increased plasma NUCB2/nesfatin-1 levels (Stengel et al. 2011), whereas those of acyl and desacyl ghrelin were decreased in conjunction with reduced food intake (Stengel et al. 2010), thus suggesting that NUCB2/nesfatin-1 and ghrelin expression might be regulated differentially. As ghrelin participates in regulating hedonic feeding (Egecioglu et al. 2010, Skibicka et al. 2012), it can be speculated that the two peptides might also interact within reward-related areas.

A summary of nesfatin-1's effects on the hedonic aspects of food intake is given in Table 1 .

\section{Gastric distension and gastric acid secretion}

NUCB2/nesfatin-1 was not only described as a direct mediator of central nervous regulation of food intake but also as a regulator of gastrointestinal functions, e.g. by slowing down gastric emptying. The latter in turn supports nesfatin-1's central nervous anorexigenic actions by eliciting peripheral satiety signals.

I.c.v. injection of an anorexigenic dose of nesfatin-1 decreased gastric emptying in fasted rats (Stengel et al. 2009a) and mice (Goebel-Stengel et al. 2011). Additionally, nesfatin-1's involvement in regulating gastroduodenal motility was also shown in mice after a central administration of nesfatin-1's midsegment (Atsuchi et al. 2010). Although it was shown previously that the $\mathrm{CRF}_{2}$ receptor is involved in the regulation of gastric motility (Czimmer et al. 2006), nesfatin-1 is recruiting other pathways than this (Stengel et al. 2009a).

The brain areas that are thought to be responsible for nesfatin-1's effects on gastrointestinal functions are the PVN, ARC, CeA and basomedial amygdala (BMA). When administered into the PVN, nesfatin-1 dose-dependently decreased gastric motility and emptying, an effect mediated by oxytocinergic neurons (Guo et al. 2015). Similarly, when injected into the ARC, CeA or BMA, nesfatin-1 decreased gastric motility and emptying by exploiting the melanocortin system (Li et al. 2013b, Wang et al. 2014, Xu et al. 2015a). Strikingly, the endogenous level of NUCB2/nesfatin-1 seems to be important in the physiological regulation of gastric functions as antiNUCB2/nesfatin-1 Ab application is also capable to alter the activity of PVN, ARC, CeA and BMA gastric distensionsensitive neurons (Li et al. 2013b, Wang et al. 2014, Guo et al. 2015, Xu et al. 2015a).

Gastric distension (e.g. a consequence of reduced gastric emptying, gastric and duodenal motility) might be relayed to the CNS to induce satiety through CCK. Interestingly, the peripheral injection of CCK increased c-fos expression in NUCB2/nesfatin-1 neurons of the SON, PVN, NTS and the area postrema (Noetzel et al. 2009, Stengel et al. 2009a, Saito et al. 2016). Conversely, nesfatin-1 at an anorexigenic dose increased Cck mRNA expression in the hypothalamus of fed and unfed goldfish (Kerbel \& Unniappan 2012). This positive feedback indicates that the two peptides act in concert to suppress food intake.

In addition to this mechanism, experimental data also support the existence of a neuronal connection between the gastrointestinal system and central nervous NUCB2/nesfatin-1 neurons. NUCB2/nesfatin-1 neurons

Published by Bioscientifica Ltd 
of the NTS, which receive gastric and intestinal afferents inputs via the vagus nerve, were activated after gastric distension in rats (Bonnet et al. 2013). In addition, oral administration of metformin reduced food intake and gastric emptying in mice, in conjunction with the activation of NUCB2/nesfatin-1 neurons in the NTS and dorsal nucleus of the vagus nerve (DMNX) (Rouquet et al. 2014).

Gastric acid secretion was also found to be affected by nesfatin-1. Particularly, a central injection of an anorexigenic dose of nesfatin- 1 is also capable to inhibit the 2-deoxy-D-glucose-stimulated gastric acid secretion via vagal efferents in rats, as suggested by a 16-fold increase of c-fos-positive neurons in the DMNX, but not in the NTS (Xia et al. 2012). In agreement, $80 \%$ of DMNX neurons projecting to the stomach are nesfatin-1 positive (as was shown by retrograde tracing) (Bonnet et al. 2013).

Thus, nesfatin- 1 appears to contribute to the regulation of food intake by directly and/or indirectly affecting the integration of input and output signals between gut and brain.

An overview of nesfatin-1's effects on gastric distension and gastric acid secretion is provided in the Supplementary Table 1.

\section{Thermogenesis}

In contrast to nesfatin-1's role in food intake regulation, its participation in the regulation of energy expenditure, the second aspect contributing to whole body energy homeostasis, is less well investigated and understood. Könczöl and coworkers provided the first evidence for a function of nesfatin-1 in energy expenditure by reporting an increase in core body temperature after its i.c.v. administration (Könczöl et al. 2012). This finding was substantiated in a study using direct calorimetry to quantify dry heat loss as a measure for thermogenesis and thus energy expenditure (Wernecke et al. 2014). In this study, i.c.v. application of nesfatin-1 increased dry heat loss of rats over eight hours to $8.49 \pm 1.09 \mathrm{~W} / \mathrm{kg} 0.75$ compared to $7.09 \pm 0.84 \mathrm{~W} / \mathrm{kg}^{0.75}$ in control animals (Wernecke et al. 2014). Thereby other structures than the PVN are involved because NUCB2 knockdown in this nucleus does not affect energy expenditure (Nakata et al. 2016).

In contrast to the findings on acute i.c.v. administration of nesfatin-1, subcutaneous (s.c.) osmotic minipump infusion for 7 days elicited a decrease of oxygen consumption and energy expenditure in the light phase, but no alteration in the dark phase in freely feeding rats (Mortazavi et al. 2015). In a short term experiment (1 day), oxygen consumption was reduced in the dark phase; this was, however, not reflected in energy expenditure calculations (Mortazavi et al. 2015). In the light phase, no alterations were observed (Mortazavi et al. 2015).

The underlying central nervous and peripheral mechanisms of nesfatin-1's impact on thermogenesis remain to be elucidated.

Nesfatin-1's effects on thermogenesis are summarized in Table 2.

\section{Glucose homeostasis}

Outside the CNS, Nucb2 mRNA was detected not only in adipose tissue but also in rodent and human pancreatic islets (Riva et al. 2011). The distribution of mRNA expression is matched by the occurrence of NUCB2/nesfatin-1 protein (Gonzalez et al. 2009, Stengel et al. 2009b, Foo et al. 2010, Riva et al. 2011), which is colocalized almost exclusively with insulin in the $\beta$-cells of pancreatic islets (Gonzalez et al. 2009, Foo et al. 2010, Riva et al. 2011). In fact, NUCB2/nesfatin-1-immunoreactivity is present in all or almost all $\beta$-cells (Foo et al. 2010, Riva et al. 2011), with a subcellular distribution distinct from insulin immunoreactivity (Foo et al. 2010). Colocalization of NUCB2/nesfatin-1 with PC1/3 and PC2 suggests that processing into nesfatin-1 may take place physiologically in pancreatic islets (Mohan et al. 2016).

In the pancreatic $\beta$-cells, intracellular NUCB2 mRNA and/or NUCB2/nesfatin-1 protein synthesis or release are dynamically regulated by glucose levels: In vitro, Nucb2 mRNA is upregulated in human islets by glucolipotoxic conditions (high glucose and palmitate) and release can be triggered by glucose stimulation in rat islets (Foo et al. 2010). This regulation seems to be impaired in glycemic diseases; e.g. in streptozotocin diabetic mice, Nucb2 mRNA and NUCB2/nesfatin-1 protein expression are significantly reduced in the pancreatic islets (Gonzalez et al. 2011b). This was confirmed in the islets of Goto-Kakizaki (GK) rats, a model of type 2 diabetes. However, the opposite was observed in mice with dietinduced obesity and as a consequence type 2 diabetes (Gonzalez et al. 2011b). Finally, islets from patients with type 2 diabetes exhibited a reduction in $N u c b 2$ mRNA compared with islets from healthy donors; this correlated significantly with insulin secretion capacity (Riva et al. 2011). However, the difference was not that marked and

Published by Bioscientifica Ltd. 


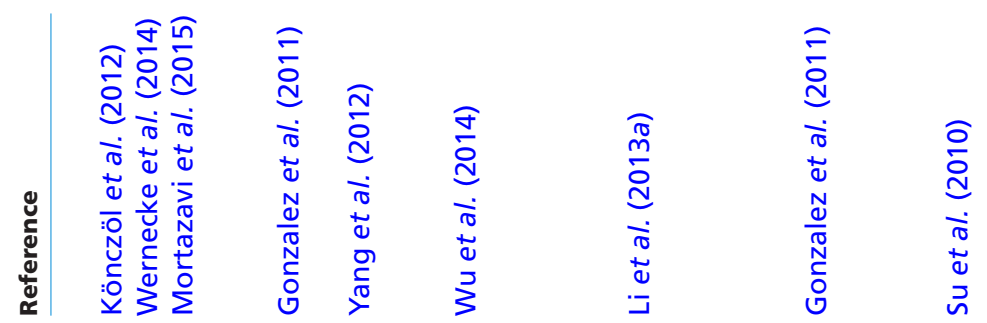
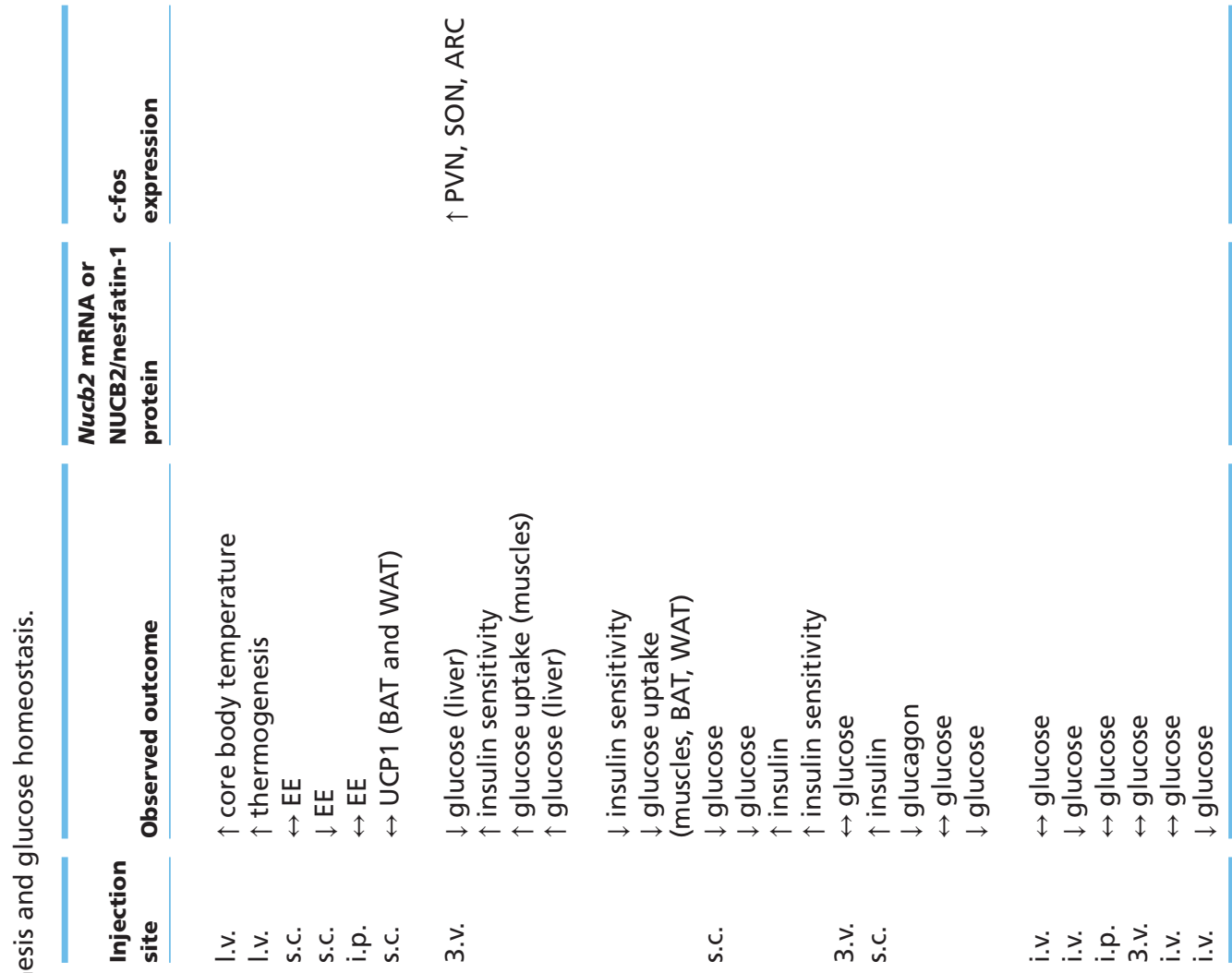

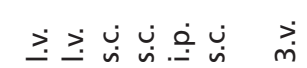
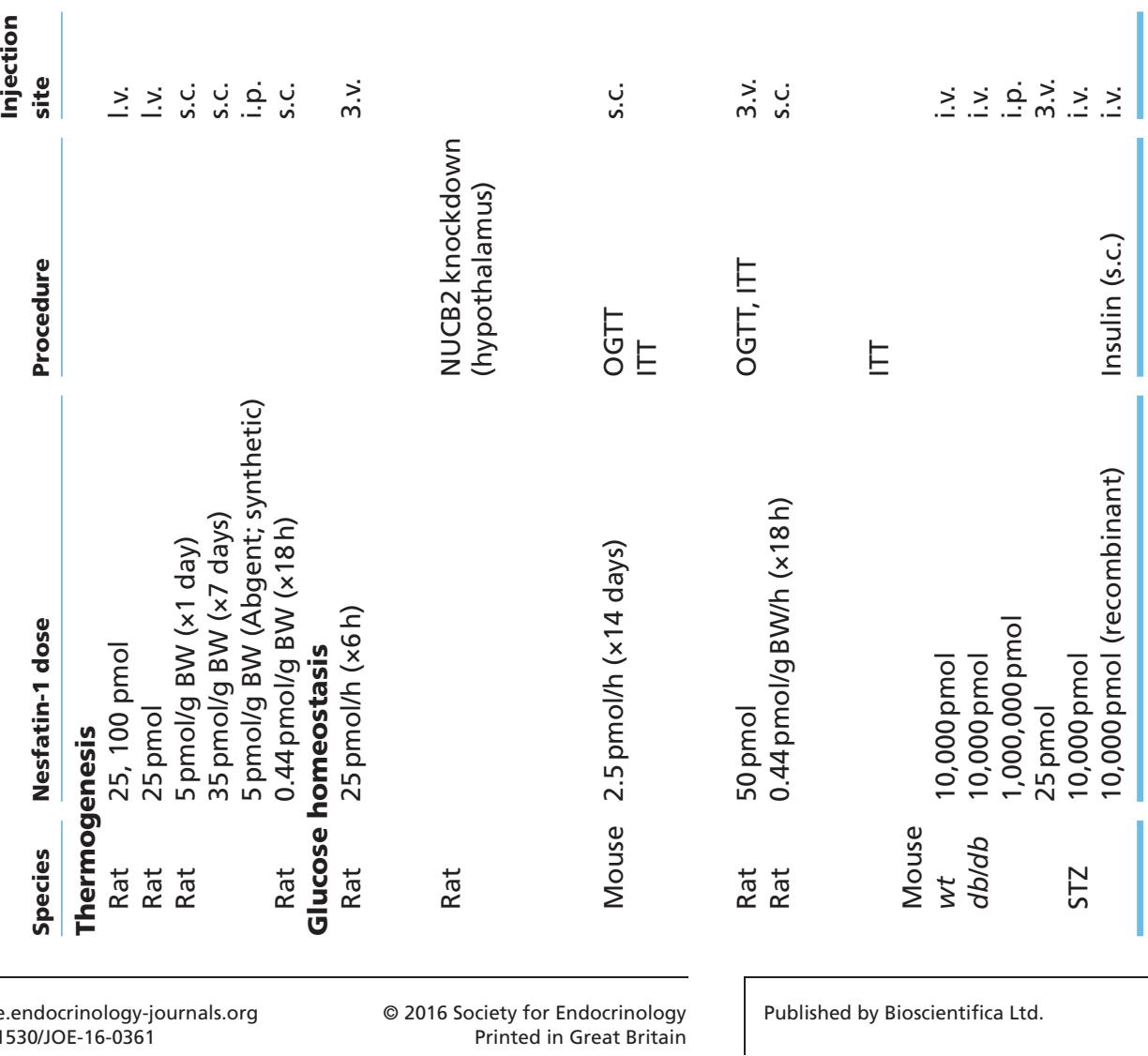
as the sample size was small, the observations should be treated with some caution (Riva et al. 2011). The data on NUCB2/nesfatin- 1 in plasma of type 2 diabetic patients are unequivocal as for type 2 patients, both increased (Zhang et al. 2012) and decreased (Li et al. 2010) levels were reported, whereas plasma NUCB2/nesfatin-1 in type 1 diabetic patients was unchanged compared with healthy individuals (Li et al. 2010). It should be noted that plasma NUCB2/nesfatin-1 most likely does not reflect pancreatic production and release but is rather derived from major sources as gastric mucosa (Stengel et al. 2009b) and adipose tissue (Ramanjaneya et al. 2010). In particular, the variable contribution of the latter might account for the conflicting findings in type 2 diabetic patients in different studies.

A few studies have addressed the effects of glucose challenge on plasma nesfatin-1 levels. Although in rats, in an i.p. glucose tolerance test, NUCB2/nesfatin-1 initially decreased and then returned to basal levels in GK rats and even overshot in healthy Wistar rats (Foo et al. 2010), gavaging with a high-carbohydrate diet was without effect on serum NUCB2/nesfatin-1 in mice (Mohan et al. 2014). In the latter, chronic exposure to a high-carbohydrate diet, however, altered the circadian pattern of serum nesfatin-1/NUCB (Mohan et al. 2014). In humans, oral glucose administration in healthy humans did not significantly affect plasma NUCB2/nesfatin-1 levels (Li et al. 2010).

Although glucose levels have an impact on $N u c b 2$ mRNA and NUCB2/nesfatin-1 protein release in pancreatic islets (Foo et al. 2010), on the other hand, nesfatin-1 enhances glucose-induced insulin secretion by promoting $\mathrm{Ca}^{2+}$ influx through L-type channels (Nakata et al. 2011). This process, unlike nesfatin1 's actions on hypothalamic neurons (Brailoiu et al. 2007), is independent of PKA (Nakata et al. 2011). Furthermore, phospholipase $\mathrm{A}_{2}\left(\mathrm{PLA}_{2}\right)$, which releases the putative second messenger arachidonic acid, crucial for glucose-stimulated insulin release (Jones \& Persaud 1993), is neither involved in nesfatin-1's insulinotropic effects (Nakata et al. 2011). Like in other areas, further advances are hampered by the not yet identified putative nesfatin-1 receptor. Of note, insulin release from pancreatic islets is only stimulated by nesfatin-1 in concentrations that exceed the plasma levels of lean subjects (Tsuchiya et al. 2010, Nakata et al. 2011). However, the local production of nesfatin-1 in the $\beta$-cells and its increased secretion by elevated glucose levels (Foo et al. 2010) might either intracellularly or in an autocrine and/or paracrine fashion, participate/ facilitate insulin release upon elevated blood glucose independently from circulating NUCB2/nesfatin-1 levels.

In vivo results from rodents are more complex and thus more difficult to interpret: continuous s.c. infusion of nesfatin-1 in rodents improved glucose utilization by enhancing insulin secretion (Gonzalez et al. 2011a, Li et al. 2013a). At the same time, due to an activation of intracellular insulin signaling, glucose uptake is ameliorated by increasing insulin sensitivity in liver, muscle and adipose tissue of mice (Li et al. 2013a). However, another study in rats could only confirm the effects on glucose uptake for the adipose tissue (Gonzalez et al. 2011a) without detecting changes in insulin signal transduction (Gonzalez et al. 2011a). Also in the myocardium, nesfatin-1 augments insulin receptor signaling to increase glucose uptake by mobilization of the glucose transporter, supposedly due to local nesfatin-1 production, which is dependent on diet and coronary health (Feijoo-Bandin et al. 2013). Interestingly, in normoglycemic fasted $d b / d b$ or freely fed wild-type mice (Su et al. 2010), blood glucose was not affected by intravenous nesfatin-1, suggesting that nesfatin-1 is able to correct a pathological hyperglycemic state, but is not of relevance in the normoglycemic range.

In the CNS, nesfatin-1's function with regard to glucose metabolism is less well investigated, but it is implied to be involved both in glucose sensing as well as in the control of glucose metabolism. For instance, the excitability of glucose responsive neurons is modulated by nesfatin-1 in the ventromedial and lateral hypothalamus (Chen et al. 2012) and the PVN, where about $27 \%$ of NUCB2/nesfatin-1 immunoreactive neurons respond to either glucose and/or insulin (Gantulga et al. 2012), the latter implying a physiological role for NUCB2/ nesfatin-1 in the modulation of glucose sensing. This seems to be specific to hypothalamic nuclei as in the NTS, another important structure for glucose sensing in the brain (Routh 2002), the response of glucose-sensing neurons is not modulated by NUCB2/nesfatin-1, despite its local expression (Mimee \& Ferguson 2015).

In both normal chow and high-fat diet fed rats, reduction of central nervous NUCB2/nesfatin-1 availability by adenoviral-mediated RNA interference induced peripheral insulin resistance, leading to an increase in hepatic glucose flux and a decrease in glucose uptake in peripheral tissues (Wu et al. 2014).

Fittingly, nesfatin-1 administered i.c.v. acts in the hypothalamus to increase whole-body insulin sensitivity by stimulating insulin receptor signaling in the liver to

Published by Bioscientifica Ltd. 
inhibit hepatic gluconeogenesis and in the muscle to improve glucose uptake (Yang et al. 2012). However, two other studies failed to observe effects of central nesfatin-1 on blood glucose, glucose tolerance and insulin sensitivity (Su et al. 2010, Li et al. 2013a).

For a compilation of nesfatin-1's effects on glucose homeostasis please refer to Table 2.

\section{Other systems}

\section{Cardiovascular actions}

Besides its well-described actions on the regulation of energy homeostasis, the central nervous administration of nesfatin-1 exerts cardiovascular effects. For example, it was shown that that i.c.v. administration of nesfatin-1 increases mean arterial pressure (MAP) (Yosten \& Samson 2009, 2010, 2014, Tanida \& Mori 2011, Tanida et al. 2015); heart rate was also found to be increased (Tanida et al. 2015); ERK phosphorylation CRF neurons of the PVN is involved in these effects (Tanida et al. 2015). Until now, it is not clear whether central nervous nesfatin- 1 activates cardiac sympathetic innervation, but it was shown that it increases renal sympathetic nerve activity (Tanida \& Mori 2011, Tanida et al. 2015), known to be involved in blood pressure regulation through the renin-angiotensin system (Nakamura \& Johns 1995).

Electrophysiological studies have identified the median NTS as a potential site through which nesfatin-1 exerts is cardiovascular actions (Mimee et al. 2012). Nucb2 mRNA and NUCB2/nesfatin-1 protein expression was observed in this nucleus (Brailoiu et al. 2007, Foo et al. 2008) and both central nervous and peripheral administration of nesfatin- 1 induce c-fos expression in its neurons (Maejima et al. 2009, Shimizu et al. 2009a). Local injection of nesfatin-1 into the median NTS increased both blood pressure and heart rate (Mimee et al. 2012). In contrast, site-specific injection into the nucleus ambiguus, a key site for parasympathetic cardiac control (Mendelowitz 1999), induced bradycardia, although MAP was not affected (Brailoiu et al. 2013). The existence of NUCB2/nesfatin-1 immunoreactivity in this nucleus in rodents (Goebel et al. 2009a, Goebel-Stengel et al. 2011) implies a physiological function of the peptide.

Nesfatin-1 involvement in cardiovascular regulation is not surprising as many neuropeptides involved in conveying nesfatin-1's anorexigenic signal are also known to contribute to the control of cardiovascular function, e.g. the melancortin system (Cone 2005).
Hyperstimulation of this system may underlie the development of hypertension in several animal models (da Silva et al. 2013, Segal-Lieberman \& Rosenthal 2013). Consequently, studies aimed at dissecting the downstream mechanisms of nesfatin-1's cardiovascular action focused on these neuropeptides by blocking their respective receptors. In particular, work from the Samson group has clarified that upon i.c.v. administration, nesfatin- 1 acts through sequential activation of POMC neurons (Yosten \& Samson 2009, Tanida \& Mori 2011), followed by oxytocin (Yosten \& Samson 2010) and then CRF (Yosten \& Samson 2014) neurons to increase blood pressure (Yosten \& Samson 2009, 2014). This circuit matches with nesfatin-1's downstream events involved in the regulation of food intake (Yosten \& Samson 2014).

In addition to its central nervous actions, intravenous administration of nesfatin-1 possesses a hypertensive effect (Yamawaki et al. 2012), potentially through acting both at the central nervous, but also at the peripheral level by modulating arterial resistance (Yamawaki et al. 2012). Both NUCB 2 and nesfatin-1 protein have been detected in the heart and nesfatin- 1 can directly control heart performance in vitro (Angelone et al. 2013).

The actions of nesfatin- 1 on the cardiovascular system are summarized in Table 3.

\section{Anxiety, behavior and depression}

A role of nesfatin-1 in regulating anxiety- and depressive-like behaviors has been suggested. As mentioned previously, substantial NUCB2/nesfatin-1 immunoreactivity was detected in brain areas known to be involved in anxiety-like behavior and stress response, such as amygdaloid nuclei, bed nucleus of the stria terminalis, PVN and hippocampus (Brailoiu et al. 2007, Fort et al. 2008, Goebel et al. 2009a, Goebel-Stengel et al. 2011). The i.c.v. administration of nesfatin-1 was shown to increase both adrenocorticotropic hormone (ACTH) and corticosterone plasma levels in rats (Könczöl et al. 2010, Yoshida et al. 2010), suggesting that nesfatin-1 might play a role in the modulation of the hypothalamuspituitary-adrenal (HPA) axis activity. Moreover, bilateral adrenalectomy increased $N u c b 2$ mRNA expression in the PVN, indicating that its expression is regulated by HPA axis activity (Könczöl et al. 2010).

In line with these data, central administration of an anorexigenic dose of nesfatin-1-induced anxiety-like behavior in rats tested in the elevated-plus maze (the gold standard test to measure unlearned anxiety response) and 

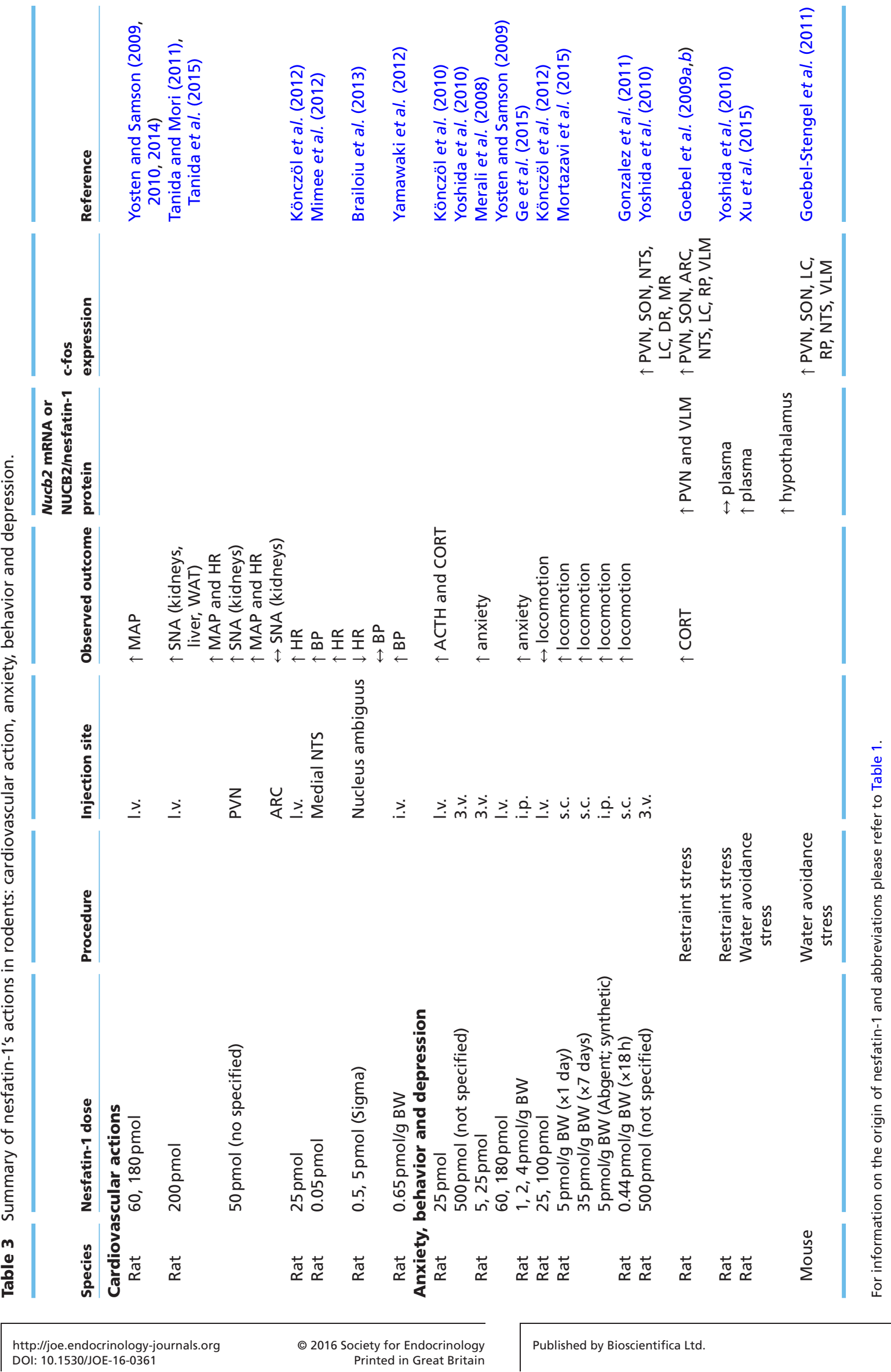
fear conditioning test (learned anxiety response) (Merali et al. 2008). In addition, when animals were exposed to a novel environment, nesfatin-1 not only increased the latency to eat palatable food but also decreased the amount consumed (Merali et al. 2008). In an open field test, both an acute central nervous (Yosten \& Samson 2009) and a peripheral chronic administration of nesfatin-1 (Ge et al. 2015) increased anxiety-like behavior. The latter was accompanied by reduced brain-derived neurotrophic factor (BDNF) and ERK 1 and 2 phosphorylation in the prefrontal cortex and hippocampus (Ge et al. 2015). Moreover, nesfatin-1-induced anxiety was blocked by the co-administration of SHU9119 (Yosten \& Samson 2009), indicating that nesfatin-1 participates in stress response mechanisms by recruiting the central melanocortin system. However, the contribution of the hypothalamic (HPA) and extrahypothalamic circuitries (e.g. amygdaloid nuclei, where nesfatin-1 is abundantly expressed (Goebel et al. 2009a, Goebel-Stengel et al. 2011)) in inducing anxiety- and fear-related behaviors has yet to be dissected.

Rats exposed to restraint stress did not show altered NUCB2/nesfatin-1 plasma levels (Yoshida et al. 2010). On the other hand, in a recent study, NUCB2/nesfatin-1 plasma levels were increased in a water avoidance test $(\mathrm{Xu}$ et al. 2015b). Such a discrepancy could be explained by the different stress tests (physical vs psychological) or other methodological differences (Yoshida et al. 2010, Xu et al. 2015b). Interestingly, NUCB2/nesfatin-1 plasma levels were positively correlated with those of corticosterone; in addition, hypothalamic Nucb2 mRNA expression levels were also found to be increased and positively correlated with those of Crf after water avoidance stress acute exposure (Xu et al. 2015b).

Exposure to restraint stress increased corticosterone serum levels (Xu et al. 2010) and c-fos expression in NUCB2/nesfatin-1 neurons of several brain areas such as PVN, SON, ARC, NTS, locus coeruleus (LC), raphe pallidus (RP) and ventrolateral medulla (VLM) (Goebel et al. 2009b, Yoshida et al. 2010). Furthermore, it increased Nucb2 mRNA expression in the PVN and VLM (Könczöl et al. 2010). Thus, the NUCB2/nesfatin-1 system is recruited under stress conditions. Together with the finding, that i.c.v. administration of nesfatin-1 increased c-fos expression in PVN, SON, NTS, LC, DR and medial raphe (Yoshida et al. 2010), central nervous NUCB2/ nesfatin-1 appears to be involved in orchestrating autonomic, neuroendocrine and behavioral responses to stress.

Matching these findings from rodent experimental models, recent data in humans also suggest that a relationship between nesfatin- 1 and stress-related mood disorders might exist. NUCB2/nesfatin-1 plasma levels of patients affected by major depressive disorders were higher than those in healthy subjects (Ari et al. 2011). Moreover, a positive correlation was found between circulating NUCB2/nesfatin-1 levels and anxiety in women diagnosed with anorexia nervosa (Hofmann et al. 2015a) or obesity (Hofmann et al. 2013, 2015b), whereas this relationship was inversed in obese men (Hofmann et al. 2015b). Intriguingly, drug-free suicide male victims displayed higher Nucb2 mRNA expression in the Edinger-Westphal nucleus than in controls, whereas levels were lower in female victims (Bloem et al. 2012).

For nesfatin-1's effects in the context of anxiety, behavior and depression, please see Table 3 .

\section{Epilepsy}

The findings on nesfatin-1 altering neuronal excitability (Price et al. 2008a,b, Mimee et al. 2012, Li et al. 2014, Chen et al. 2015) led researchers to investigate the role of this peptide in neurological disorders such as epilepsy, characterized by imbalanced excitatory and inhibitory neuronal inputs. Subjects diagnosed with primary generalized epilepsy had higher saliva and serum nesfatin-1 levels than control (Aydin et al. 2009). This increase could be reduced by antiepileptic drug treatment (Aydin et al. 2009). In addition, serum nesfatin-1 levels were found to be higher in epileptic patients up to $48 \mathrm{~h}$ after an epileptic attack than in healthy subjects (Aydin et al. 2011). Fittingly, kainic acid-induced epileptic seizures increased plasma NUCB2/nesfatin-1 levels in rats (Liu et al. 2011). Whether NUCB2/nesfatin-1 plays a facilitative or inhibitory role in triggering epilepsy seizures and in the pathophysiology of epilepsy remains to be determined.

\section{Sleep}

As the discovery of co-expression of NUCB2/nesfatin- 1 and melanin-concentrating hormone protein $(\mathrm{MCH})$ in the THA (Fort et al. 2008), a central nervous structure, which is closely related to the regulation of rapid eye movement (REM) sleep (Luppi et al. 2006), a few studies have aimed at investigating potential functional connections between NUCB2/nesfatin-1 protein or Nucb2 mRNA expression and sleep.

Published by Bioscientifica Ltd. 
It was shown that abolishment of REM sleep reduces Nucb2 mRNA and NUCB2/nesfatin-1 protein expression in the dorsal lateral hypothalamus, whose lateral hypothalamus subsection (Papp \& Palkovits 2014) is among others involved the regulation of the sleep and wake cycle. REM sleep rebound in turn activates NUCB2/nesfatin-1 neurons (Vas et al. 2013). Data on REM sleep alterations upon nesfatin-1 i.c.v. injection are unequivocal as both a reduction (Vas et al. 2013) as well as a slight increase (Jego et al. 2012) have been published; in line with the latter observation, blockade of endogenous nesfatin-1 expression negatively affects REM sleep (Jego et al. 2012).

Besides these few functional studies, in human sleep apnea syndrome an inverse correlation between NUCB2/ nesfatin-1 in peripheral circulation and the severity of disease was observed (Aksu et al. 2015, Araz et al. 2015, Shen et al. 2015), whether there is a functional link remains to be elucidated.

\section{Reproduction}

Reproductive maturation and function are closely linked to the availability of energy, thereby placing priority to survival of the individual over the thriving of a population. Known endocrine mediators linking metabolic state and reproduction are, e.g., insulin and leptin. Both act at the hypothalamic level to convey information about the metabolic state to gonadotropin-releasing hormone (GnRH) neurons in the PVN and thus in turn control the hypothalamic-pituitary-gonadal (HPG) axis (Hill et al. 2008).

Recent data suggest that also NUCB2/nesfatin-1 is involved in the interaction between energy status and reproduction (Garcia-Galiano \& Tena-Sempere 2013, Navarro \& Kaiser 2013), particularly with respect to the regulation of female pubertal transition, during which Nucb2 mRNA and protein expression were significantly increased in the hypothalamus (Garcia-Galiano et al. 2010). In contrast, during this developmental stage, a negative energy balance decreased both $N u c b 2$ mRNA and protein expression (Garcia-Galiano et al. 2010). Furthermore, central nervous administration of nesfatin-1-induced luteinizing hormone (LH) secretion in freely feeding and to an even greater extent also in short-term fasted pubertal female rats (Garcia-Galiano et al. 2010). Fittingly, morpholino oligonucleotideinduced knockdown of hypothalamic Nucb2 mRNA expression delayed pubertal transition and reduced LH levels and the weights of the ovaries. Food intake was not affected in these animals, suggesting a direct effect of NUCB2/nesfatin-1 on pubertal maturation (GarciaGaliano et al. 2010).

To date, there is only limited information available on whether nesfatin-1 is also involved in the regulation of the adult HPG axis: in adult female rats, 50 pmol nesfatin-1 i.c.v. did not affect plasma LH (Garcia-Galiano et al. 2010). Preliminary data, which were only presented at two conferences, indicate that upon i.c.v. administration of a very high dose of nesfatin-1 (1 nmol), plasma LH and follicle-stimulating hormone (FSH) were increased in male rats (Tadross et al. 2010, Patterson et al. 2011). Conversely, in the pituitary, Nucb2 mRNA expression is regulated by 17-estradiol and progesterone sex steroids, suggesting the existence of a feedback-mechanism in the NUCB2/nesfatin-1-HPGaxis interaction (Garces et al. 2014).

In a recently published study, however, i.c.v. administration of nesfatin-1 significantly reduced the expression of GnRH mRNA in the hypothalamus and FSH and LH mRNA in the pituitary (Gao et al. 2016), suggesting an inhibitory role of nesfatin-1 on the HPG axis. Matching observations were also made in fish after peripheral administration of nesfatin-1 (Gonzalez et al. 2012).

The downstream mediators of nesfatin-1 in the context of reproduction have not yet been identified; however, neuropeptides such as oxytocin and a-MSH are known to regulate GnRH action and thus are potential candidates (Parent et al. 2008, Roa \& Herbison 2012). Furthermore, the recently discovered neuropeptide phoenixin, which is colocalized with NUCB2/nesfatin-1 in a number of hypothalamic nuclei (ARC, PVN, ventromedial and lateral hypothalamus) (Palasz et al. 2015) has been suggested as a potential mediator for nesfatin-1's action with regard to reproduction. Phoenixin increases GnRH, GnRH receptor and Kiss1 gene expression (Yosten et al. 2013, Treen et al. 2016) and potentiates GnRH-stimulated LH release in vitro (Yosten et al. 2013). These findings were substantiated by an in vivo study demonstrating that i.c.v. phoenixin dose dependently increased plasma LH in diestrus female rats (Stein et al. 2016).

In the periphery, NUCB2/nesfatin-1 immunoreactivity has been detected in rodent and human testes' Leydig cells; in rat testes, Nucb2 mRNA and NUCB2/nesfatin-1 are controlled by the pituitary (Garcia-Galiano et al. 2012). During pubertal transition, NUCB2/nesfatin-1 protein (but not mRNA) was significantly increased and was suppressed by short-term food deprivation (GarciaGaliano et al. 2012), resembling the findings in the

Published by Bioscientifica Ltd. 
hypothalamic of female rats under the same conditions (Garcia-Galiano et al. 2010). Furthermore, Nucb2 mRNA and NUCB2/nesfatin-1 protein expression in rat placenta and also plasma NUCB2/nesfatin-1 decrease in the course of gestation (Garces et al. 2014).

\section{Supplementary data}

This is linked to the online version of the paper at http://dx.doi.org/10.1530/ JOE-16-0361.

\section{Declaration of interest}

The authors declare that there is no conflict of interest that could be perceived as prejudicing the impartiality of this review.

\section{Funding}

This work was made possible by grants of the Deutsche Forschungsgemeinschaft to H L and C S (GRK 1957 and TR-SFB134) and of the DDS - Deutsche Diabetes Stiftung (333/02/13) to C S.

\section{Acknowledgements}

The authors thank Jens Mittag and Olaf Jöhren for fruitful discussion.

\section{References}

Aksu O, Aydin B, Doguc DK, Ilhan I, Ozturk O, Altuntas A, Demirkan H, Koroglu BK \& Tamer MN 2015 The evaluation of Nesfatin-1 levels in patients with OSAS associated with metabolic syndrome. Journal of Endocrinological Investigation 38 463-469. (doi:10.1007/s40618-0140216-0)

Angelone T, Filice E, Pasqua T, Amodio N, Galluccio M, Montesanti G, Quintieri AM \& Cerra MC 2013 Nesfatin-1 as a novel cardiac peptide: identification, functional characterization, and protection against ischemia/reperfusion injury. Cellular and Molecular Life Sciences 70 495-509. (doi:10.1007/s00018-012-1138-7)

Araz O, Yilmazel UE, Dorman E, Bayraktutan Z, Yayla M, Yilmaz N, Acemoglu H, Halici Z \& Akgun M 2015 Is there a relationship between obstructive sleep apnea syndrome severity and nesfatin-1? Respiration 90 105-110. (doi:10.1159/000431180)

Ari M, Ozturk OH, Bez Y, Oktar S \& Erduran D 2011 High plasma nesfatin-1 level in patients with major depressive disorder. Progress in Neuro-Psychopharmacology and Biological Psychiatry 35 497-500. (doi:10.1016/j.pnpbp.2010.12.004)

Atsuchi K, Asakawa A, Ushikai M, Ataka K, Tsai M, Koyama K, Sato Y, Kato I, Fujimiya M \& Inui A 2010 Centrally administered nesfatin-1 inhibits feeding behaviour and gastroduodenal motility in mice. Neuroreport 21 1008-1011. (doi:10.1097/wnr.0b013e32833f7b96)

Aydin S, Dag E, Ozkan Y, Erman F, Dagli AF, Kilic N, Sahin I, Karatas F, Yoldas T, Barim AO, et al. 2009 Nesfatin-1 and ghrelin levels in serum and saliva of epileptic patients: hormonal changes can have a major effect on seizure disorders. Molecular and Cellular Biochemistry 328 49-56. (doi:10.1007/s11010-009-0073-x)

Aydin S, Dag E, Ozkan Y, Arslan O, Koc G, Bek S, Kirbas S, Kasikci T, Abasli D, Gokcil Z, et al. 2011 Time-dependent changes in the serum levels of prolactin, nesfatin-1 and ghrelin as a marker of epileptic attacks young male patients. Peptides 32 1276-1280. (doi:10.1016/j. peptides.2011.04.021)
Barnikol-Watanabe S, Gross NA, Gotz H, Henkel T, Karabinos A, Kratzin H, Barnikol HU \& Hilschmann N 1994 Human protein NEFA, a novel DNA binding/EF-hand/leucine zipper protein. Molecular cloning and sequence analysis of the cDNA, isolation and characterization of the protein. Biological Chemistry Hoppe-Seyler $\mathbf{3 7 5}$ 497-512. (doi:10.1515/bchm3.1994.375.8.497)

Bloem B, Xu L, Morava E, Faludi G, Palkovits M, Roubos EW \& Kozicz T 2012 Sex-specific differences in the dynamics of cocaine- and amphetamine-regulated transcript and nesfatin- 1 expressions in the midbrain of depressed suicide victims vs. controls. Neuropharmacology 62 297-303. (doi:10.1016/j.neuropharm.2011.07.023)

Bonnet MS, Ouelaa W, Tillement V, Trouslard J, Jean A, Gonzalez BJ, Gourcerol G, Dallaporta M, Troadec JD \& Mounien L 2013 Gastric distension activates NUCB2/nesfatin-1-expressing neurons in the nucleus of the solitary tract. Regulatory Peptides 187 17-23. (doi:10.1016/j.regpep.2013.10.001)

Brailoiu GC, Dun SL, Brailoiu E, Inan S, Yang J, Chang JK \& Dun NJ 2007 Nesfatin-1: distribution and interaction with a $G$ protein-coupled receptor in the rat brain. Endocrinology 148 5088-5094. (doi:10.1210/ en.2007-0701)

Brailoiu GC, Deliu E, Tica AA, Rabinowitz JE, Tilley DG, Benamar K, Koch WJ \& Brailoiu E 2013 Nesfatin-1 activates cardiac vagal neurons of nucleus ambiguus and elicits bradycardia in conscious rats. Journal of Neurochemistry 126 739-748. (doi:10.1111/jnc.12355)

Brunner L, Nick HP, Cumin F, Chiesi M, Baum HP, Whitebread S, Stricker-Krongrad A \& Levens N 1997 Leptin is a physiologically important regulator of food intake. International Journal of Obesity and Related Metabolic Disorders 21 1152-1160. (doi:10.1038/ sj.ijo.0800529)

Celik A, Gurger M, Can C, Balin M, Gul E, Kobat MA, Gumusay U, Sahan M, Bursal KB, Celiker I, et al. 2013 The effect of nesfatin-1 levels on paroxysmal supraventricular tachycardia. Journal of Investigative Medicine 61 852-855. (doi:10.2310/ JIM.0b013e31828dedd2)

Chen X, Dong J \& Jiang ZY 2012 Nesfatin-1 influences the excitability of glucosensing neurons in the hypothalamic nuclei and inhibits the food intake. Regulatory Peptides 177 21-26. (doi:10.1016/j. regpep.2012.04.003)

Chen YY, Chan RM, Tan KM, Poh LK, Loke KY, Wang JP, Li H, Hu YH, Wang L, Lee KO, et al. 2013 The association of a nucleobindin 2 gene (NUCB2) variant with childhood adiposity. Gene 516 48-52. (doi:10.1016/j.gene.2012.12.017)

Chen X, Shu X, Cong ZK, Jiang ZY \& Jiang H 2015 Nesfatin-1 acts on the dopaminergic reward pathway to inhibit food intake. Neuropeptides 53 45-50. (doi:10.1016/j.npep.2015.07.004)

Cone RD 2005 Anatomy and regulation of the central melanocortin system. Nature Neuroscience 8 571-578. (doi:10.1038/nn1455)

Cox BM, Young AB, See RE \& Reichel CM 2013 Sex differences in methamphetamine seeking in rats: impact of oxytocin. Psychoneuroendocrinology 38 2343-2353. (doi:10.1016/j. psyneuen.2013.05.005)

Crujeiras AB, Carreira MC, Cabia B, Andrade S, Amil M \& Casanueva FF 2015 Leptin resistance in obesity: an epigenetic landscape. Life Science 140 57-63. (doi:10.1016/j.lfs.2015.05.003)

Czimmer J, Million M \& Taché Y 2006 Urocortin 2 acts centrally to delay gastric emptying through sympathetic pathways while CRF and urocortin 1 inhibitory actions are vagal dependent in rats. American Journal of Physiology: Gastrointestinal and Liver Physiology 290 G511-G518. (doi:10.1152/ajpgi.00289.2005)

da Silva AA, do Carmo JM \& Hall JE 2013 Role of leptin and central nervous system melanocortins in obesity hypertension. Current Opinion in Nephrology and Hypertension 22 135-140. (doi:10.1097/ MNH.0b013e32835d0c05)

Darambazar G, Nakata M, Okada T, Wang L, Li E, Shinozaki A, Motoshima M, Mori M \& Yada T 2015 Paraventricular NUCB2/ nesfatin- 1 is directly targeted by leptin and mediates its anorexigenic 
effect. Biochemical and Biophysical Research Communications 456 913-918. (doi:10.1016/j.bbrc.2014.12.065)

Egecioglu E, Jerlhag E, Salome N, Skibicka KP, Haage D, Bohlooly Y, Andersson D, Bjursell M, Perrissoud D, Engel JA, et al. 2010 Ghrelin increases intake of rewarding food in rodents. Addiction Biology 15 304-311. (doi:10.1111/j.1369-1600.2010.00216.x)

Feijoo-Bandin S, Rodriguez-Penas D, Garcia-Rua V, Mosquera-Leal A, Otero MF, Pereira E, Rubio J, Martinez I, Seoane LM, Gualillo O, et al. 2013 Nesfatin-1 in human and murine cardiomyocytes: synthesis, secretion, and mobilization of GLUT-4. Endocrinology 154 4757-4767. (doi:10.1210/en.2013-1497)

Fliedner S, Schulz C \& Lehnert H 2006 Brain uptake of intranasally applied radioiodinated leptin in Wistar rats. Endocrinology 147 2088-2094. (doi:10.1210/en.2005-1016)

Foo KS, Brismar H \& Broberger C 2008 Distribution and neuropeptide coexistence of nucleobindin-2 mRNA/nesfatin-like immunoreactivity in the rat CNS. Neuroscience 156 563-579. (doi:10.1016/j. neuroscience.2008.07.054)

Foo KS, Brauner H, Ostenson CG \& Broberger C 2010 Nucleobindin-2/ nesfatin in the endocrine pancreas: distribution and relationship to glycaemic state. Journal of Endocrinology 204 255-263. (doi:10.1677/ JOE-09-0254)

Fort P, Salvert D, Hanriot L, Jego S, Shimizu H, Hashimoto K, Mori M \& Luppi PH 2008 The satiety molecule nesfatin-1 is co-expressed with melanin concentrating hormone in tuberal hypothalamic neurons of the rat. Neuroscience 155 174-181. (doi:10.1016/j. neuroscience.2008.05.035)

Gantulga D, Maejima Y, Nakata M \& Yada T 2012 Glucose and insulin induce $\mathrm{Ca} 2+$ signaling in nesfatin-1 neurons in the hypothalamic paraventricular nucleus. Biochemical and Biophysical Research Communications 420 811-815. (doi:10.1016/j.bbrc.2012.03.079)

Gao X, Zhang K, Song M, Li X, Luo L, Tian Y, Zhang Y, Li Y, Zhang X, Ling Y, et al. 2016 Role of nesfatin-1 in the reproductive axis of male rat. Scientific Reports 6 32877. (doi:10.1038/srep32877)

Garces MF, Poveda NE, Sanchez E, Sanchez AY, Bravo SB, Vazquez MJ, Dieguez C, Nogueiras R \& Caminos JE 2014 Regulation of NucB2/ Nesfatin-1 throughout rat pregnancy. Physiology and Behavior 133 216-222. (doi:10.1016/j.physbeh.2014.05.042)

Garcia-Galiano D \& Tena-Sempere M 2013 Emerging roles of NUCB2/ nesfatin-1 in the metabolic control of reproduction. Current Pharmaceutical Design 19 6966-6972. (doi:10.2174/13816128193913 1127142531)

Garcia-Galiano D, Navarro VM, Roa J, Ruiz-Pino F, Sanchez-Garrido MA, Pineda R, Castellano JM, Romero M, Aguilar E, Gaytan F, et al. 2010 The anorexigenic neuropeptide, nesfatin-1, is indispensable for normal puberty onset in the female rat. Journal of Neuroscience $\mathbf{3 0}$ 7783-7792. (doi:10.1523/JNEUROSCI.5828-09.2010)

Garcia-Galiano D, Pineda R, Ilhan T, Castellano JM, Ruiz-Pino F, Sanchez-Garrido MA, Vazquez MJ, Sangiao-Alvarellos S, RomeroRuiz A, Pinilla L, et al. 2012 Cellular distribution, regulated expression, and functional role of the anorexigenic peptide, NUCB2/ nesfatin-1, in the testis. Endocrinology 153 1959-1971. (doi:10.1210/ en.2011-2032)

Ge JF, Xu YY, Qin G, Pan XY, Chen JQ \& Chen FH 2015 Nesfatin-1, a potent anorexic agent, decreases exploration and induces anxiety-like behavior in rats without altering learning or memory. Brain Research 1629 171-181. (doi:10.1016/j.brainres.2015.10.027)

Giannoni P, Passani MB, Nosi D, Chazot PL, Shenton FC, Medhurst AD, Munari L \& Blandina P 2009 Heterogeneity of histaminergic neurons in the tuberomammillary nucleus of the rat. European Journal of Neuroscience 29 2363-2374. (doi:10.1111/j.1460-9568.2009.06765.x)

Gil-Campos M, Aguilera CM, Canete R \& Gil A 2006 Ghrelin: a hormone regulating food intake and energy homeostasis. British Journal of Nutrition 96 201-226. (doi:10.1079/BJN20061787)

Goebel M, Stengel A, Wang L, Lambrecht NW \& Taché Y 2009a Nesfatin-1 immunoreactivity in rat brain and spinal cord autonomic nuclei. Neuroscience Letters 452 241-246. (doi:10.1016/j. neulet.2009.01.064)

Goebel M, Stengel A, Wang L \& Taché Y $2009 b$ Restraint stress activates nesfatin-1-immunoreactive brain nuclei in rats. Brain Research 1300 114-124. (doi:10.1016/j.brainres.2009.08.082)

Goebel M, Stengel A, Wang L \& Taché Y 2011 Central nesfatin-1 reduces the nocturnal food intake in mice by reducing meal size and increasing inter-meal intervals. Peptides 32 36-43. (doi:10.1016/j. peptides.2010.09.027)

Goebel-Stengel M, Wang L, Stengel A \& Taché Y 2011 Localization of nesfatin-1 neurons in the mouse brain and functional implication. Brain Research 1396 20-34. (doi:10.1016/j.brainres.2011.04.031)

Gonzalez R, Tiwari A \& Unniappan S 2009 Pancreatic beta cells colocalize insulin and pronesfatin immunoreactivity in rodents. Biochemical and Biophysical Research Communications 381 643-648. (doi:10.1016/j. bbrc.2009.02.104)

Gonzalez R, Perry RL, Gao X, Gaidhu MP, Tsushima RG, Ceddia RB \& Unniappan S 2011a Nutrient responsive nesfatin-1 regulates energy balance and induces glucose-stimulated insulin secretion in rats. Endocrinology 152 3628-3637. (doi:10.1210/en.2010-1471)

Gonzalez R, Reingold BK, Gao X, Gaidhu MP, Tsushima RG \& Unniappan S $2011 b$ Nesfatin-1 exerts a direct, glucose-dependent insulinotropic action on mouse islet beta- and MIN6 cells. Journal of Endocrinology 208 R9-R16. (doi:10.1530/joe-10-0492)

Gonzalez R, Shepperd E, Thiruppugazh V, Lohan S, Grey CL, Chang JP \& Unniappan S 2012 Nesfatin-1 regulates the hypothalamo-pituitaryovarian axis of fish. Biology of Reproduction 87 84. (doi:10.1095/ biolreprod.112.099630)

Gotoh K, Masaki T, Chiba S, Ando H, Shimasaki T, Mitsutomi K, Fujiwara K, Katsuragi I, Kakuma T, Sakata T, et al. 2013 Nesfatin-1, corticotropin-releasing hormone, thyrotropin-releasing hormone, and neuronal histamine interact in the hypothalamus to regulate feeding behavior. Journal of Neurochemistry 124 90-99. (doi:10.1111/jnc.12066)

Guo FF, Xu L, Gao SL, Sun XR, Li ZL \& Gong YL 2015 The effects of nesfatin-1 in the paraventricular nucleus on gastric motility and its potential regulation by the lateral hypothalamic area in rats. Journal of Neurochemistry 132 266-275. (doi:10.1111/jnc.12973)

Hill JW, Elmquist JK \& Elias CF 2008 Hypothalamic pathways linking energy balance and reproduction. American Journal of Physiology: Endocrinology and Metabolism 294 E827-E832. (doi:10.1152/ ajpendo.00670.2007)

Hindmarch C, Fry M, Yao ST, Smith PM, Murphy D \& Ferguson AV 2008 Microarray analysis of the transcriptome of the subfornical organ in the rat: regulation by fluid and food deprivation. American Journal of Physiology: Regulatory, Integrative and Comparative Physiology 295 R1914-R1920. (doi:10.1152/ajpregu.90560.2008)

Hofmann T, Stengel A, Ahnis A, Busse P, Elbelt U \& Klapp BF 2013 NUCB2/nesfatin-1 is associated with elevated scores of anxiety in female obese patients. Psychoneuroendocrinology 38 2502-2510. (doi:10.1016/j.psyneuen.2013.05.013)

Hofmann T, Ahnis A, Elbelt U, Rose M, Klapp BF \& Stengel A $2015 a$ NUCB2/nesfatin-1 is associated with elevated levels of anxiety in anorexia nervosa. PLOS ONE 10 e0132058. (doi:10.1371/journal. pone.0132058)

Hofmann T, Elbelt U, Ahnis A, Rose M, Klapp BF \& Stengel A $2015 b$ Sex-specific regulation of NUCB2/nesfatin-1: differential implication in anxiety in obese men and women. Psychoneuroendocrinology 60 130-137. (doi:10.1016/j.psyneuen.2015.06.014)

Huo L, Grill HJ \& Bjorbaek C 2006 Divergent regulation of proopiomelanocortin neurons by leptin in the nucleus of the solitary tract and in the arcuate hypothalamic nucleus. Diabetes 55 567-573. (doi:10.2337/diabetes.55.03.06.db05-1143)

Ilango A, Kesner AJ, Keller KL, Stuber GD, Bonci A \& Ikemoto S 2014 Similar roles of substantia nigra and ventral tegmental dopamine neurons in reward and aversion. Journal of Neuroscience 34 817-822. (doi:10.1523/JNEUROSCI.1703-13.2014) 
Inhoff T, Monnikes H, Noetzel S, Stengel A, Goebel M, Dinh QT, Riedl A, Bannert N, Wisser AS, Wiedenmann B, et al. 2008 Desacyl ghrelin inhibits the orexigenic effect of peripherally injected ghrelin in rats. Peptides 29 2159-2168. (doi:10.1016/j.peptides.2008.09.014)

Inhoff T, Stengel A, Peter L, Goebel M, Taché Y, Bannert N, Wiedenmann B, Klapp BF, Monnikes H \& Kobelt P 2010 Novel insight in distribution of nesfatin-1 and phospho-mTOR in the arcuate nucleus of the hypothalamus of rats. Peptides 31 257-262. (doi:10.1016/j.peptides.2009.11.024)

Ishida E, Hashimoto K, Shimizu H, Okada S, Satoh T, Kato I, Yamada M \& Mori M 2012 Nesfatin-1 induces the phosphorylation levels of cAMP response element-binding protein for intracellular signaling in a neural cell line. PLoS ONE 7 e50918. (doi:10.1371/journal. pone.0050918)

Iwasaki Y, Nakabayashi H, Kakei M, Shimizu H, Mori M \& Yada T 2009 Nesfatin-1 evokes Ca2+ signaling in isolated vagal afferent neurons via Ca2+ influx through N-type channels. Biochemical and Biophysical Research Communications 390 958-962. (doi:10.1016/j. bbrc.2009.10.085)

Jego S, Salvert D, Renouard L, Mori M, Goutagny R, Luppi PH \& Fort P 2012 Tuberal hypothalamic neurons secreting the satiety molecule Nesfatin-1 are critically involved in paradoxical (REM) sleep homeostasis. PLOS ONE 7 e52525. (doi:10.1371/journal. pone.0052525)

Jones PM \& Persaud SJ 1993 Arachidonic acid as a second messenger in glucose-induced insulin secretion from pancreatic beta-cells. Journal of Endocrinology 137 7-14. (doi:10.1677/joe.0.1370007)

Kerbel B \& Unniappan S 2012 Nesfatin-1 suppresses energy intake, co-localises ghrelin in the brain and gut, and alters ghrelin, cholecystokinin and orexin mRNA expression in goldfish. Journal of Neuroendocrinology 24 366-377. (doi:10.1111/j.13652826.2011.02246.x)

Kim J, Chung Y, Kim H, Im E, Lee H \& Yang H 2014 The tissue distribution of nesfatin-1/NUCB2 in mouse. Development and Reproduction 18 301-309. (doi:10.12717/DR.2014.18.4.301)

Kohno D, Nakata M, Maejima Y, Shimizu H, Sedbazar U, Yoshida N, Dezaki K, Onaka T, Mori M \& Yada T 2008 Nesfatin-1 neurons in paraventricular and supraoptic nuclei of the rat hypothalamus coexpress oxytocin and vasopressin and are activated by refeeding. Endocrinology 149 1295-1301. (doi:10.1210/en.2007-1276)

Könczöl K, Bodnar I, Zelena D, Pinter O, Papp RS, Palkovits M, Nagy GM \& Toth ZE 2010 Nesfatin-1/NUCB2 may participate in the activation of the hypothalamic-pituitary-adrenal axis in rats. Neurochemistry International 57 189-197. (doi:10.1016/j.neuint.2010.04.012)

Könczöl K, Pinter O, Ferenczi S, Varga J, Kovacs K, Palkovits M, Zelena D \& Toth ZE 2012 Nesfatin-1 exerts long-term effect on food intake and body temperature. International Journal of Obesity 36 1514-1521. (doi:10.1038/ijo.2012.2)

Kuksis M \& Ferguson AV 2014 Cellular actions of nesfatin-1 in the subfornical organ. Journal of Neuroendocrinology 26 237-246. (doi:10.1111/jne.12143)

Li QC, Wang HY, Chen X, Guan HZ \& Jiang ZY 2010 Fasting plasma levels of nesfatin- 1 in patients with type 1 and type 2 diabetes mellitus and the nutrient-related fluctuation of nesfatin-1 level in normal humans. Regulatory Peptides 159 72-77. (doi:10.1016/j. regpep.2009.11.003)

Li Z, Gao L, Tang H, Yin Y, Xiang X, Li Y, Zhao J, Mulholland M \& Zhang W 2013a Peripheral effects of nesfatin-1 on glucose homeostasis. PLoS ONE 8 e71513. (doi:10.1371/journal. pone.0071513)

Li ZL, Xu L, Sun XR, Guo FF, Gong YL \& Gao SL 2013b Central nesfatin-1 influences the excitability of ghrelin-responsive gastric distension neurons in the arcuate nucleus and reduces gastric motility in rats. European Journal of Neuroscience 38 3636-3643. (doi:10.1111/ ejn.12366)
Li C, Zhang F, Shi L, Zhang H, Tian Z, Xie J \& Jiang H 2014 Nesfatin-1 decreases excitability of dopaminergic neurons in the substantia nigra. Journal of Molecular Neuroscience 52 419-424. (doi:10.1007/ s12031-013-0169-3)

Liu Z, Wang F, Li ZZ, Qi JH, Xu WZ, Zhang PS \& Sun T 2011 Expression of neuropeptides ghrelin and Nesfatin-1 in kainic acid kindling rats. Zhonghua Yi Xue Za Zhi 91 496-500.

Luppi PH, Gervasoni D, Verret L, Goutagny R, Peyron C, Salvert D, Leger L \& Fort P 2006 Paradoxical (REM) sleep genesis: the switch from an aminergic-cholinergic to a GABAergic-glutamatergic hypothesis. Journal of Physiology 100 271-283. (doi:10.1016/j.jphysparis.2007.05.006)

Maejima Y, Sedbazar U, Suyama S, Kohno D, Onaka T, Takano E, Yoshida N, Koike M, Uchiyama Y, Fujiwara K, et al. 2009 Nesfatin1-regulated oxytocinergic signaling in the paraventricular nucleus causes anorexia through a leptin-independent melanocortin pathway. Cell Metabolism 10 355-365. (doi:10.1016/j.cmet.2009.09.002)

Masaki T, Chiba S, Yasuda T, Noguchi H, Kakuma T, Watanabe T, Sakata T \& Yoshimatsu H 2004 Involvement of hypothalamic histamine H1 receptor in the regulation of feeding rhythm and obesity. Diabetes $\mathbf{5 3}$ 2250-2260. (doi:10.2337/diabetes.53.9.2250)

Mendelowitz D 1999 Advances in parasympathetic control of heart rate and cardiac function. News in Physiological Science 14 155-161.

Merali Z, Cayer C, Kent P \& Anisman H 2008 Nesfatin-1 increases anxiety- and fear-related behaviors in the rat. Psychopharmacology 201 115-123. (doi:10.1007/s00213-008-1252-2)

Mimee A \& Ferguson AV 2015 Glycemic state regulates melanocortin, but not nesfatin-1, responsiveness of glucose-sensing neurons in the nucleus of the solitary tract. American Journal of Physiology: Regulatory, Integrative and Comparative Physiology 308 R690-R699. (doi:10.1152/ ajpregu.00477.2014)

Mimee A, Smith PM \& Ferguson AV 2012 Nesfatin-1 influences the excitability of neurons in the nucleus of the solitary tract and regulates cardiovascular function. American Journal of Physiology: Regulatory, Integrative and Comparative Physiology 302 R1297-R1304. (doi:10.1152/ajpregu.00266.2011)

Miura K, Titani K, Kurosawa Y \& Kanai Y 1992 Molecular cloning of nucleobindin, a novel DNA-binding protein that contains both a signal peptide and a leucine zipper structure. Biochemical and Biophysical Research Communications 187 375-380. (doi:10.1016/ S0006-291X(05)81503-7)

Mohan H, Ramesh N, Mortazavi S, Le A, Iwakura H \& Unniappan S 2014 Nutrients differentially regulate nucleobindin-2/nesfatin- 1 in vitro in cultured stomach ghrelinoma (MGN3-1) cells and in vivo in male mice. PLOS ONE 9 e115102. (doi:10.1371/journal.pone.0115102)

Mohan H, Gasner M, Ramesh N \& Unniappan S 2016 Ghrelin, ghrelinO-acyl transferase, nucleobindin-2/nesfatin-1 and prohormone convertases in the pancreatic islets of Sprague Dawley rats during development. Journal of Molecular Histology 47 325-336. (doi:10.1007/ s10735-016-9673-4)

Moreau JM \& Ciriello J 2013 Nesfatin-1 induces Fos expression and elicits dipsogenic responses in subfornical organ. Behavioural Brain Research 250 343-350. (doi:10.1016/j.bbr.2013.05.036)

Mortazavi S, Gonzalez R, Ceddia R \& Unniappan S 2015 Long-term infusion of nesfatin-1 causes a sustained regulation of whole-body energy homeostasis of male Fischer 344 rats. Frontiers in Cell and Developmental Biology 3 22. (doi:10.3389/fcell.2015.00022)

Nakamura A \& Johns EJ 1995 Renal nerves, renin, and angiotensinogen gene expression in spontaneously hypertensive rats. Hypertension $\mathbf{2 5}$ 581-586. (doi:10.1161/01.HYP.25.4.581)

Nakata M, Manaka K, Yamamoto S, Mori M \& Yada T 2011 Nesfatin-1 enhances glucose-induced insulin secretion by promoting $\mathrm{Ca}(2+)$ influx through L-type channels in mouse islet beta-cells. Endocrine Journal 58 305-313. (doi:10.1507/endocrj.K11E-056)

Nakata M, Gantulga D, Santoso P, Zhang B, Masuda C, Mori M, Okada T \& Yada T 2016 Paraventricular NUCB2/nesfatin-1 supports oxytocin and http://joe.endocrinology-journals.org

DOI: 10.1530/JOE-16-0361
() 2016 Society for Endocrinology Printed in Great Britain
Published by Bioscientifica Ltd 
vasopressin neurons to control feeding behavior and fluid balance in male mice. Endocrinology 157 2322-2332. (doi:10.1210/en.2015-2082)

Navarro VM \& Kaiser UB 2013 Metabolic influences on neuroendocrine regulation of reproduction. Current Opinion in Endocrinology, Diabetes and Obesity 20 335-341. (doi:10.1097/MED.0b013e32836318ce)

Noetzel S, Stengel A, Inhoff T, Goebel M, Wisser AS, Bannert N, Wiedenmann B, Klapp BF, Taché Y, Monnikes H, et al. 2009 CCK-8S activates c-Fos in a dose-dependent manner in nesfatin-1 immunoreactive neurons in the paraventricular nucleus of the hypothalamus and in the nucleus of the solitary tract of the brainstem. Regulatory Peptides 157 84-91. (doi:10.1016/j. regpep.2009.06.009)

Nonogaki K, Ohba Y, Sumii M \& Oka Y 2008 Serotonin systems upregulate the expression of hypothalamic NUCB2 via 5-HT2C receptors and induce anorexia via a leptin-independent pathway in mice. Biochemical and Biophysical Research Communications $\mathbf{3 7 2}$ 186-190. (doi:10.1016/j.bbrc.2008.05.010)

Oh-I S, Shimizu H, Satoh T, Okada S, Adachi S, Inoue K, Eguchi H, Yamamoto M, Imaki T, Hashimoto K, et al. 2006 Identification of nesfatin-1 as a satiety molecule in the hypothalamus. Nature $\mathbf{4 4 3}$ 709-712. (doi:10.1038/nature05162)

Oh-I S, Shimizu H \& Mori M 2013 Nesfatin-1. In Handbook of Biologically Active Peptides, 2nd Edition, pp 1271-1274. Ed A Kastin. Cambridge, MA, USA: Academic Press.

Ott V, Finlayson G, Lehnert H, Heitmann B, Heinrichs M, Born J \& Hallschmid M 2013 Oxytocin reduces reward-driven food intake in humans. Diabetes 62 3418-3425. (doi:10.2337/db13-0663)

Ozcan M, Betul ZG, Emine K, Serhatlioglu I \& Kelestimur H 2016 Nesfatin-1 increases intracellular calcium concentration by protein kinase $\mathrm{C}$ activation in cultured rat dorsal root ganglion neurons. Neuroscience Letters 619 177-181. (doi:10.1016/j.neulet.2016.03.018)

Palasz A, Rojczyk E, Bogus K, Worthington JJ \& Wiaderkiewicz R 2015 The novel neuropeptide phoenixin is highly co-expressed with nesfatin-1 in the rat hypothalamus, an immunohistochemical study. Neuroscience Letters 592 17-21. (doi:10.1016/j. neulet.2015.02.060)

Pan W, Hsuchou H \& Kastin AJ 2007 Nesfatin-1 crosses the blood-brain barrier without saturation. Peptides 28 2223-2228. (doi:10.1016/j. peptides.2007.09.005)

Pandit R, van der Zwaal EM, Luijendijk MC, Brans MA, van Rozen AJ, Oude Ophuis RJ, Vanderschuren LJ, Adan RA \& la Fleur SE 2015 Central melanocortins regulate the motivation for sucrose reward. PLOS ONE 10 e0121768. (doi:10.1371/journal.pone.0121768)

Pandit R, Omrani A, Luijendijk MC, de Vrind VA, van Rozen AJ, Ophuis RJ, Garner K, Kallo I, Ghanem A, Liposits Z, et al. 2016 Melanocortin 3 receptor signaling in midbrain dopamine neurons increases the motivation for food reward. Neuropsychopharmacology 41 2241-2251. (doi:10.1038/ npp.2016.19)

Papp RS \& Palkovits M 2014 Brainstem projections of neurons located in various subdivisions of the dorsolateral hypothalamic area-an anterograde tract-tracing study. Frontiers in Neuroanatomy 834. (doi:10.3389/fnana.2014.00034)

Parent AS, Rasier G, Matagne V, Lomniczi A, Lebrethon MC, Gerard A, Ojeda SR \& Bourguignon JP 2008 Oxytocin facilitates female sexual maturation through a glia-to-neuron signaling pathway. Endocrinology 149 1358-1365. (doi:10.1210/en.2007-1054)

Patterson M, Wynne K, Patel S, Suzuki K, Tadross J, Ghatei M \& Bloom S 2011 Nesfatin stimulates the hypothalamic-pituitary-gonadal axis in male rats. Endocrine Abstracts 25279 (available at: http://www. endocrine-abstracts.org/ea/0025/ea0025p279.htm).

Perello M, Stuart RC \& Nillni EA 2007 Differential effects of fasting and leptin on proopiomelanocortin peptides in the arcuate nucleus and in the nucleus of the solitary tract. American Journal of Physiology: Endocrinology and Metabolism 292 E1348-E1357. (doi:10.1152/ ajpendo.00466.2006)
Price TO, Samson WK, Niehoff ML \& Banks WA 2007 Permeability of the blood-brain barrier to a novel satiety molecule nesfatin-1. Peptides $\mathbf{2 8}$ 2372-2381. (doi:10.1016/j.peptides.2007.10.008)

Price CJ, Hoyda TD, Samson WK \& Ferguson AV 2008 $a$ Nesfatin-1 influences the excitability of paraventricular nucleus neurones Journal of Neuroendocrinology 20 245-250. (doi:10.1111/j.13652826.2007.01641.x)

Price CJ, Samson WK \& Ferguson AV 2008 $b$ Nesfatin-1 inhibits NPY neurons in the arcuate nucleus. Brain Research 1230 99-106. (doi:10.1016/j.brainres.2008.06.084)

Prinz P, Teuffel P, Lembke V, Kobelt P, Goebel-Stengel M, Hofmann T, Rose M, Klapp BF \& Stengel A 2015 Nesfatin-130-59 injected intracerebroventricularly differentially affects food intake microstructure in rats under normal weight and diet-induced obese conditions. Frontiers in Neuroscience 9 422. (doi:10.3389/ fnins.2015.00422)

Prinz P, Goebel-Stengel M, Teuffel P, Rose M, Klapp BF \& Stengel A 2016 Peripheral and central localization of the nesfatin-1 receptor using autoradiography in rats. Biochemical and Biophysical Research Communications 470 521-527. (doi:10.1016/j.bbrc.2016.01.113)

Ramanjaneya M, Chen J, Brown JE, Tripathi G, Hallschmid M, Patel S, Kern W, Hillhouse EW, Lehnert H, Tan BK, et al. 2010 Identification of nesfatin-1 in human and murine adipose tissue: a novel depot-specific adipokine with increased levels in obesity. Endocrinology 151 3169-3180. (doi:10.1210/en.2009-1358)

Ramesh N, Mortazavi S \& Unniappan S 2016 Nesfatin-1 stimulates cholecystokinin and suppresses peptide YY expression and secretion in mice. Biochemical and Biophysical Research Communications 472 201-208. (doi:10.1016/j.bbrc.2016.02.095)

Riva M, Nitert MD, Voss U, Sathanoori R, Lindqvist A, Ling C \& Wierup N 2011 Nesfatin-1 stimulates glucagon and insulin secretion and beta cell NUCB2 is reduced in human type 2 diabetic subjects. Cell and Tissue Research 346 393-405. (doi:10.1007/ s00441-011-1268-5)

Roa J \& Herbison AE 2012 Direct regulation of GnRH neuron excitability by arcuate nucleus POMC and NPY neuron neuropeptides in female mice. Endocrinology 153 5587-5599. (doi:10.1210/en.2012-1470)

Rojczyk E, Palasz A \& Wiaderkiewicz R 2015 Effect of short and longterm treatment with antipsychotics on orexigenic/anorexigenic neuropeptides expression in the rat hypothalamus. Neuropeptides $\mathbf{5 1}$ 31-42. (doi:10.1016/j.npep.2015.04.001)

Rouquet T, Clement P, Gaige S, Tardivel C, Roux J, Dallaporta M, Bariohay B, Troadec JD \& Lebrun B 2014 Acute oral metformin enhances satiation and activates brainstem nesfatinergic neurons. Obesity 22 2552-2562. (doi:10.1002/oby.20902)

Routh VH 2002 Glucose-sensing neurons: are they physiologically relevant? Physiology and Behavior 76 403-413. (doi:10.1016/S00319384(02)00761-8)

Sabatier N, Leng G \& Menzies J 2013 Oxytocin, feeding, and satiety. Frontiers in Endocrinology 4 35. (doi:10.3389/fendo.2013.00035)

Saito R, So M, Motojima Y, Matsuura T, Yoshimura M, Hashimoto H, Yamamoto Y, Kusuhara K \& Ueta Y 2016 Activation of nesfatin-1-containing neurons in the hypothalamus and brainstem by peripheral administration of anorectic hormones and suppression of feeding via central nesfatin-1 in rats. Journal of Neuroendocrinology 28. (doi:10.1111/jne.12400)

Saper CB, Chou TC \& Elmquist JK 2002 The need to feed: homeostatic and hedonic control of eating. Neuron 36 199-211. (doi:10.1016/ S0896-6273(02)00969-8)

Schulz C, Paulus K \& Lehnert H 2004 Central nervous and metabolic effects of intranasally applied leptin. Endocrinology 145 2696-2701. (doi:10.1210/en.2003-1431)

Schulz C, Paulus K, Johren O \& Lehnert H 2012 Intranasal leptin reduces appetite and induces weight loss in rats with diet-induced obesity (DIO). Endocrinology 153 143-153. (doi:10.1210/en.2011-1586) 
Sedbazar U, Ayush EA, Maejima Y \& Yada T 2014 Neuropeptide $\mathrm{Y}$ and alpha-melanocyte-stimulating hormone reciprocally regulate nesfatin-1 neurons in the paraventricular nucleus of the hypothalamus. Neuroreport 25 1453-1458. (doi:10.1097/ WNR.0000000000000293)

Segal-Lieberman G \& Rosenthal T 2013 Animal models in obesity and hypertension. Current Hypertension Reports 15 190-195. (doi:10.1007/ s11906-013-0338-3)

Seidah NG \& Prat A 2002 Precursor convertases in the secretory pathway, cytosol and extracellular milieu. Essays in Biochemistry 38 79-94. (doi:10.1042/bse0380079)

Shen P, Han Y, Cai B \& Wang Y 2015 Decreased levels of serum nesfatin-1 in patients with obstructive sleep apnea syndrome. Sleep and Breathing 19 515-522. (doi:10.1007/s11325-014-1039-0)

Shimizu H, Oh-I S, Hashimoto K, Nakata M, Yamamoto S, Yoshida N, Eguchi H, Kato I, Inoue K, Satoh T, et al. 2009a Peripheral administration of nesfatin-1 reduces food intake in mice: the leptin-independent mechanism. Endocrinology 150 662-671. (doi:10.1210/en.2008-0598)

Shimizu H, Oh-I S, Okada S \& Mori M 2009b Nesfatin-1: an overview and future clinical application. Endocrine Journal 56 537-543. (doi:10.1507/endocrj.K09E-117)

Skibicka KP, Hansson C, Egecioglu E \& Dickson SL 2012 Role of ghrelin in food reward: impact of ghrelin on sucrose self-administration and mesolimbic dopamine and acetylcholine receptor gene expression. Addiction Biology 17 95-107. (doi:10.1111/j.1369-1600.2010.00294.x)

Stein LM, Tullock CW, Mathews SK, Garcia-Galiano D, Elias CF, Samson WK \& Yosten GL 2016 Hypothalamic action of phoenixin to control reproductive hormone secretion in females: importance of the orphan G protein-coupled receptor Gpr173. American Journal of Physiology: Regulatory, Integrative and Comparative Physiology $\mathbf{3 1 1}$ R489-R496. (doi:10.1152/ajpregu.00191.2016)

Steiner DF, Smeekens SP, Ohagi S \& Chan SJ 1992 The new enzymology of precursor processing endoproteases. Journal of Biological Chemistry 267 23435-23438.

Stengel A \& Taché Y 2009 Regulation of food intake: the gastric X/A-like endocrine cell in the spotlight. Current Gastroenterology Reports $\mathbf{1 1}$ 448-454. (doi:10.1007/s11894-009-0069-4)

Stengel A, Goebel M, Wang L, Rivier J, Kobelt P, Monnikes H, Lambrecht NW \& Taché Y 2009a Central nesfatin-1 reduces darkphase food intake and gastric emptying in rats: differential role of corticotropin-releasing factor2 receptor. Endocrinology 150 4911-4919. (doi:10.1210/en.2009-0578)

Stengel A, Goebel M, Yakubov I, Wang L, Witcher D, Coskun T, Taché Y, Sachs G \& Lambrecht NW 2009b Identification and characterization of nesfatin-1 immunoreactivity in endocrine cell types of the rat gastric oxyntic mucosa. Endocrinology 150 232-238. (doi:10.1210/ en.2008-0747)

Stengel A, Goebel M, Wang L, Reeve JR Jr, Taché Y \& Lambrecht NW 2010 Lipopolysaccharide differentially decreases plasma acyl and desacyl ghrelin levels in rats: potential role of the circulating ghrelinacylating enzyme GOAT. Peptides 31 1689-1696. (doi:10.1016/j. peptides.2010.06.015)

Stengel A, Goebel-Stengel M, Jawien J, Kobelt P, Taché Y \& Lambrecht NW 2011 Lipopolysaccharide increases gastric and circulating NUCB2/nesfatin-1 concentrations in rats. Peptides 32 1942-1947. (doi:10.1016/j.peptides.2011.07.006)

Stengel A, Goebel-Stengel M, Wang L, Kato I, Mori M \& Taché Y 2012 Nesfatin-1(30-59) but not the N- and C-terminal fragments, nesfatin-1(1-29) and nesfatin-1(60-82) injected intracerebroventricularly decreases dark phase food intake by increasing inter-meal intervals in mice. Peptides 35 143-148. (doi:10.1016/j.peptides.2012.03.015)

Su Y, Zhang J, Tang Y, Bi F \& Liu JN 2010 The novel function of nesfatin-1: anti-hyperglycemia. Biochemical and Biophysical Research Communications 391 1039-1042. (doi:10.1016/j.bbrc.2009.12.014)
Tadross JA, Patterson M, Wynne KJ, Patel S, Suzuki K, Ghatei MA \& Bloom SR 2010 Nesfatin suppresses feeding and stimulates the hypothalamo-pituitary-gonadal axis. 14th International Congress of Endocrinology S442.

Tanida M \& Mori M 2011 Nesfatin-1 stimulates renal sympathetic nerve activity in rats. Neuroreport 22 309-312. (doi:10.1097/ WNR.0b013e328346107f)

Tanida M, Gotoh H, Yamamoto N, Wang M, Kuda Y, Kurata Y, Mori M \& Shibamoto T 2015 Hypothalamic nesfatin-1 stimulates sympathetic nerve activity via hypothalamic ERK signaling. Diabetes 64 3725-3736. (doi:10.2337/db15-0282)

Tragante V, Barnes MR, Ganesh SK, Lanktree MB, Guo W, Franceschini N, Smith EN, Johnson T, Holmes MV, Padmanabhan S, et al. 2014 Genecentric meta-analysis in 87,736 individuals of European ancestry identifies multiple blood-pressure-related loci. American Journal of Human Genetics 94 349-360. (doi:10.1016/j.ajhg.2013.12.016)

Treen AK, Luo V \& Belsham DD 2016 Phoenixin activates immortalized GnRH and kisspeptin neurons through the novel receptor GPR173. Molecular Endocrinology 30 872-888. (doi:10.1210/me.2016-1039)

Tsuchiya T, Shimizu H, Yamada M, Osaki A, Oh-I S, Ariyama Y, Takahashi H, Okada S, Hashimoto K, Satoh T, et al. 2010 Fasting concentrations of nesfatin-1 are negatively correlated with body mass index in non-obese males. Clinical Endocrinology 73 484-490. (doi:10.1111/j.1365-2265.2010.03835.x)

Vas S, Adori C, Konczol K, Katai Z, Pap D, Papp RS, Bagdy G, Palkovits M \& Toth ZE 2013 Nesfatin-1/NUCB2 as a potential new element of sleep regulation in rats. PLOS ONE 8 e59809. (doi:10.1371/journal. pone.0059809)

Wang Q, Guo F, Sun X, Gao S, Li Z, Gong Y \& Xu L 2014 Effects of exogenous nesfatin-1 on gastric distention-sensitive neurons in the central nucleus of the amygdala and gastric motility in rats. Neuroscience Letters 582 65-70. (doi:10.1016/j.neulet.2014.09.003)

Wang R, Wang J \& Wan X 2016 Association of the polymorphism in nucleobindin 2 gene and the risk of metabolic syndrome. Genetic Testing and Molecular Biomarkers 20 49-52. (doi:10.1089/ gtmb.2015.0194)

Wernecke K, Lamprecht I, Johren O, Lehnert H \& Schulz C 2014 Nesfatin-1 increases energy expenditure and reduces food intake in rats. Obesity 22 1662-1668. (doi:10.1002/oby.20736)

Wren AM, Small CJ, Ward HL, Murphy KG, Dakin CL, Taheri S, Kennedy AR, Roberts GH, Morgan DG, Ghatei MA, et al. 2000 The novel hypothalamic peptide ghrelin stimulates food intake and growth hormone secretion. Endocrinology 141 4325-4328. (doi:10.1210/endo.141.11.7873)

Wren AM, Seal LJ, Cohen MA, Brynes AE, Frost GS, Murphy KG, Dhillo WS, Ghatei MA \& Bloom SR 2001 Ghrelin enhances appetite and increases food intake in humans. Journal of Clinical Endocrinology and Metabolism 86 5992. (doi:10.1210/jcem.86.12.8111)

Wu D, Yang M, Chen Y, Jia Y, Ma ZA, Boden G, Li L \& Yang G 2014 Hypothalamic nesfatin-1/NUCB2 knockdown augments hepatic gluconeogenesis that is correlated with inhibition of mTOR-STAT3 signaling pathway in rats. Diabetes 63 1234-1247. (doi:10.2337/db130899)

Xia ZF, Fritze DM, Li JY, Chai B, Zhang C, Zhang W \& Mulholland MW 2012 Nesfatin-1 inhibits gastric acid secretion via a central vagal mechanism in rats. American Journal of Physiology: Gastrointestinal and Liver Physiology 303 G570-G577. (doi:10.1152/ajpgi.00178.2012)

Xu L, Bloem B, Gaszner B, Roubos EW \& Kozicz T 2010 Stress-related changes in the activity of cocaine- and amphetamine-regulated transcript and nesfatin neurons in the midbrain non-preganglionic Edinger-Westphal nucleus in the rat. Neuroscience 170 478-488. (doi:10.1016/j.neuroscience.2010.07.001)

Xu L, Wang Q, Guo F, Pang M, Sun X, Gao S \& Gong Y 2015a Nesfatin-1 signaling in the basom edial amygdala modulates the gastric distension-sensitive neurons discharge and decreases gastric motility via melanocortin $3 / 4$ receptors and modified by the arcuate nucleus.

Published by Bioscientifica Ltd. 
European Journal of Pharmacology 764 164-172. (doi:10.1016/j. ejphar.2015.07.002)

Xu YY, Ge JF, Qin G, Peng YN, Zhang CF, Liu XR, Liang LC, Wang ZZ, Chen FH \& Li J 2015b Acute, but not chronic, stress increased the plasma concentration and hypothalamic mRNA expression of NUCB2/nesfatin-1 in rats. Neuropeptides 54 53. (doi:10.1016/j. npep.2015.08.003)

Yamawaki H, Takahashi M, Mukohda M, Morita T, Okada M \& Hara Y 2012 A novel adipocytokine, nesfatin-1 modulates peripheral arterial contractility and blood pressure in rats. Biochemical and Biophysical Research Communications 418 676-681. (doi:10.1016/j. bbrc.2012.01.076)

Yang M, Zhang Z, Wang C, Li K, Li S, Boden G, Li L \& Yang G 2012 Nesfatin-1 action in the brain increases insulin sensitivity through Akt/AMPK/TORC2 pathway in diet-induced insulin resistance. Diabetes 61 1959-1968. (doi:10.2337/db11-1755)

Ying J, Zhang Y, Gong S, Chang Z, Zhou X, Li H, Tao J \& Zhang G 2015 Nesfatin-1 suppresses cardiac L-type $\mathrm{Ca}(2)(+)$ channels through melanocortin type 4 receptor and the novel protein kinase $\mathrm{C}$ theta isoform pathway. Cellular Physiology and Biochemistry 36 555-568. (doi:10.1159/000430120)

Yoshida N, Maejima Y, Sedbazar U, Ando A, Kurita H, Damdindorj B, Takano E, Gantulga D, Iwasaki Y, Kurashina T, et al. 2010 Stressorresponsive central nesfatin- 1 activates corticotropin-releasing hormone, noradrenaline and serotonin neurons and evokes hypothalamicpituitary-adrenal axis. Aging 2 775-784. (doi:10.18632/aging.100207)

Yoshimura M, Matsuura T, Ohkubo J, Maruyama T, Ishikura T, Hashimoto H, Kakuma T, Mori M \& Ueta Y 2014 A role of nesfatin-1/ NucB2 in dehydration-induced anorexia. American Journal of Physiology: Regulatory, Integrative and Comparative Physiology $\mathbf{3 0 7}$ R225-R236. (doi:10.1152/ajpregu.00488.2013)

Yosten GL \& Samson WK 2009 Nesfatin-1 exerts cardiovascular actions in brain: possible interaction with the central melanocortin system.
American Journal of Physiology: Regulatory, Integrative and Comparative Physiology 297 R330-R336. (doi:10.1152/ajpcell.00009.2009)

Yosten GL \& Samson WK 2010 The anorexigenic and hypertensive effects of nesfatin-1 are reversed by pretreatment with an oxytocin receptor antagonist. American Journal of Physiology: Regulatory, Integrative and Comparative Physiology 298 R1642-R1647. (doi:10.1152/ ajpregu.00804.2009)

Yosten GL \& Samson WK 2014 Neural circuitry underlying the central hypertensive action of nesfatin-1: melanocortins, corticotropinreleasing hormone, and oxytocin. American Journal of Physiology: Regulatory, Integrative and Comparative Physiology 306 R722-R727. (doi:10.1152/ajpregu.00396.2013)

Yosten GL, Redlinger L \& Samson WK 2012 Evidence for a role of endogenous nesfatin- 1 in the control of water drinking. Journal of Neuroendocrinology 24 1078-1084. (doi:10.1111/j.13652826.2012.02304.x)

Yosten GL, Lyu RM, Hsueh AJ, Avsian-Kretchmer O, Chang JK, Tullock CW, Dun SL, Dun N \& Samson WK 2013 A novel reproductive peptide, phoenixin. Journal of Neuroendocrinology 25 206-215. (doi:10.1111/j.1365-2826.2012.02381.x)

Zegers D, Beckers S, Mertens IL, Van Gaal LF \& Van Hul W 2011 Association between polymorphisms of the Nesfatin gene, NUCB2, and obesity in men. Molecular Genetics and Metabolism 103 282-286. (doi:10.1016/j.ymgme.2011.03.007)

Zegers D, Beckers S, de Freitas F, Jennes K, Van Camp JK, Mertens IL, Van Hoorenbeeck K, Rooman RP, Desager KN, Massa G, et al. 2012 Identification of mutations in the NUCB2/nesfatin gene in children with severe obesity. Molecular Genetics and Metabolism 107 729-734. (doi:10.1016/j.ymgme.2012.10.014)

Zhang Z, Li L, Yang M, Liu H, Boden G \& Yang G 2012 Increased plasma levels of nesfatin-1 in patients with newly diagnosed type 2 diabetes mellitus. Experimental and Clinical Endocrinology and Diabetes 120 91-95. (doi:10.1055/s-0031-1286339)

Received in final form 14 September 2016

Accepted 17 October 2016

Accepted Preprint published online 17 October 2016
๑) 2016 Society for Endocrinology Printed in Great Britain 